\title{
Surface Coating-Modulated Phytotoxic Responses of Silver Nanoparticles in Plants and Freshwater Green Algae
}

\author{
Renata Biba ${ }^{\dagger}$, Karla Košpić ${ }^{\dagger}$, Bruno Komazec $^{\dagger}$, Dora Markulin, Petra Cvjetko, Dubravko Pavoković (1), \\ Petra Peharec Štefanić $(\mathbb{D}$, Mirta Tkalec and Biljana Balen * (D)
}

Department of Biology, Faculty of Science, University of Zagreb, Horvatovac 102a, HR-10000 Zagreb, Croatia; renata.biba@biol.pmf.hr (R.B.); karla.kospic@biol.pmf.hr (K.K.); bruno.komazec@biol.pmf.hr (B.K.); dora.markulin@biol.pmf.hr (D.M.); pcvjetko@biol.pmf.hr (P.C.); dubravko@biol.pmf.hr (D.P.); ppeharec@biol.pmf.hr (P.P.Š.); mtkalec@biol.pmf.hr (M.T.)

* Correspondence: bbalen@biol.pmf.hr

+ These authors equally contributed to this work.

check for updates

Citation: Biba, R.; Košpić, K.;

Komazec, B.; Markulin, D.; Cvjetko,

P.; Pavoković, D.; Peharec Štefanić, P.; Tkalec, M.; Balen, B. Surface Coating-Modulated Phytotoxic Responses of Silver Nanoparticles in Plants and Freshwater Green Algae. Nanomaterials 2022, 12, 24. https:/ / doi.org/10.3390/nano12010024

Academic Editors: Marta Marmiroli and Elena Maestri

Received: 25 November 2021 Accepted: 18 December 2021 Published: 22 December 2021

Publisher's Note: MDPI stays neutral with regard to jurisdictional claims in published maps and institutional affiliations.

Copyright: (C) 2021 by the authors. Licensee MDPI, Basel, Switzerland. This article is an open access article distributed under the terms and conditions of the Creative Commons Attribution (CC BY) license (https:// creativecommons.org/licenses/by/ $4.0 /)$.

\begin{abstract}
Silver nanoparticles (AgNPs) have been implemented in a wide range of commercial products, resulting in their unregulated release into aquatic as well as terrestrial systems. This raises concerns over their impending environmental effects. Once released into the environment, they are prone to various transformation processes that modify their reactivity. In order to increase AgNP stability, different stabilizing coatings are applied during their synthesis. However, coating agents determine particle size and shape and influence their solubility, reactivity, and overall stability as well as their behavior and transformations in the biological medium. In this review, we attempt to give an overview on how the employment of different stabilizing coatings can modulate AgNP-induced phytotoxicity with respect to growth, physiology, and gene and protein expression in terrestrial and aquatic plants and freshwater algae.
\end{abstract}

Keywords: silver nanoparticles; plants; green algae; growth; photosynthesis; oxidative stress; gene expression; protein expression

\section{Introduction}

Among a variety of applied nanomaterials, silver nanoparticles (AgNPs) attract a lot of attention due to their prominent antimicrobial effects. Therefore, they have been implemented in a wide range of commercial products such as industrial, household, and healthcare-related items, medical devices, textiles, food packaging, optical sensors, and cosmetics [1,2]. Unceasing production and utilization of AgNPs consequently results in their unregulated release into aquatic as well as terrestrial systems through numerous pathways, which raises concerns over their impending environmental effects [3,4].

AgNP stability and susceptibility to transformation upon synthesis are directly related to their surface chemistry, mostly size, charge, chemical functionality, and hydrophilicity [5]. The most important processes that impact bioavailability and biological effects of AgNPs are agglomeration and aggregation, which result in the formation of larger particles, oxidation of elemental silver $\left(\mathrm{Ag}^{0}\right)$ to silver ion $\left(\mathrm{Ag}^{+}\right)$, and subsequent dissolution to dissolved $\mathrm{Ag}^{+}$species, thus modifying the AgNP reactivity [6]. De Leersnyder et al. [7] recently emphasized that stabilization mechanism, aging, and environment significantly influence AgNP stability, as well. Studies have shown that after release into the environment, AgNPs can undergo numerous transformation reactions. These transformations include slow oxidative dissolution by $\mathrm{O}_{2}$ and protons, reactions with sulphide, chloride, and organic matter [8-10] as well as adsorption of polymers or proteins [6,11]. Observed modifications can have a strong impact on AgNP initial properties and thus reduce their mobility and modify initial concentration (reviewed in Tkalec et al. [1]). In order to prevent AgNP agglomeration and aggregation, different stabilizing coatings, such as carboxylic acids 
(citrate), polymers (polyvinylpyrrolidone, PVP), polysaccharides (gum arabic, GA), and surfactants (cetyltrimethylammonium bromide, CTAB, and sodium dodecyl sulphate, SDS) are applied during their synthesis. However, coating agents can change AgNP surfaces and thus affect their behavior and transformations in the medium [9]. Moreover, coating agents also determine particle size and shape and influence their solubility, reactivity, and overall stability $[12,13]$.

Plants, being sessile organisms, are prone to accumulation of many environmentally released substances, including AgNPs, and are, in this respect, particularly affected. Therefore, there is an ascending number of studies that investigate potential phytotoxicity of AgNPs. So far, mostly negative impact of AgNP exposure on growth, morphology, and physiology of vascular plants has been reported, although some positive effects have also been found (reviewed in Tkalec et al. [1]). Moreover, it was also discovered that AgNPs often induce oxidative stress and trigger altered gene expression, which, as a consequence, results in changes of protein expression (reviewed in Biba et al. [13]). On the other hand, AgNP toxic effects on the growth and physiology of freshwater algae are far less documented, although they are an important component of water environment and ecosystem. Most of the studies have been performed on the two species of green algae, Chlamydomonas reinhardtii and Chlorella vulgaris, in which cellular internalization and biotransformation of AgNPs have been investigated [14] as well as AgNP effect on growth and photosynthesis [15-22] (Table 1). AgNP-induced impact on growth and photosynthetic parameters were also examined in Raphidocelis subcapitata [23-25], Scenedesmus sp. [26], and in Pithophora oedogonia and Chara vulgaris [27] (Table 1). Only a few studies performed on freshwater algae have investigated AgNP influence on oxidative stress induction [21,25] and protein expression [21,28,29].

Table 1. Effects of differently coated AgNPs on fresh water green algae. Studies are listed chronologically according to the number of studies performed on particular algal species.

\begin{tabular}{|c|c|c|c|c|c|c|}
\hline $\begin{array}{l}\text { Algae } \\
\text { Species }\end{array}$ & $\begin{array}{l}\text { AgNP Coating/ } \\
\text { size (nm) }\end{array}$ & $\begin{array}{c}\text { AgNP } \\
\text { Concentration }\end{array}$ & $\begin{array}{c}\text { Exposure } \\
\text { Medium/Duration }\end{array}$ & $\begin{array}{l}\text { Investigated } \\
\text { Parameters }\end{array}$ & Findings & Reference \\
\hline \multirow[t]{5}{*}{$\begin{array}{l}\text { Chlamydomonas } \\
\text { reinhardtii }\end{array}$} & $\begin{array}{l}\text { carbonate } / 10 \text { to } 200 ; \\
\text { most } \\
\text { particles around } 25\end{array}$ & $\begin{array}{l}10 \text { to } 100000 \\
\text { nmol L }\end{array}$ & $\begin{array}{c}10 \mathrm{mmol} \mathrm{L}^{-1} \\
\text { MOPS/ } \\
1 \text { and } 2 \mathrm{~h}\end{array}$ & photosynthesis & $\begin{array}{c}\text { inhibitory } \\
\text { effects on } \\
\text { photosynthesis }\end{array}$ & [15] \\
\hline & $\begin{array}{c}\text { carbonate/ } \\
29\end{array}$ & $0.5-10 \mu \mathrm{mol} \mathrm{L}-1$ & $\begin{array}{c}10 \mathrm{mmol} \mathrm{L}^{-1} \\
\text { MOPS/ } \\
1 \mathrm{~h}\end{array}$ & bioaccumulation & $\begin{array}{l}\text { Ag content } \\
\text { increased with } \\
\text { increasing } \\
\text { exposure time } \\
\text { and AgNP conc., } \\
\text { reaching steady } \\
\text { state conc. } \\
\text { between } 10^{-5} \\
\text { and } 10^{-3} \\
\text { mol L }{ }^{-1} \text { per cell }\end{array}$ & [16] \\
\hline & $\begin{array}{c}\text { uncoated/ } \\
50\end{array}$ & $\begin{array}{c}1,5 \text {, and } \\
10 \mathrm{mmol} \mathrm{L}^{-1}\end{array}$ & $\begin{array}{c}\mathrm{HSM} / \\
6 \mathrm{~h}\end{array}$ & photosynthesis & $\begin{array}{l}\text { deteriorating } \\
\text { effect on the } \\
\text { structural and } \\
\text { functional } \\
\text { integrity of PSII }\end{array}$ & [17] \\
\hline & $\begin{array}{c}\text { PEG/ } \\
80 \pm 13\end{array}$ & $\begin{array}{l}2 \times 10^{-5} \mathrm{~mol} \mathrm{~L}^{-1} \\
2 \times 10^{-6} \mathrm{~mol} \mathrm{~L}^{-1}\end{array}$ & $\begin{array}{l}\text { Uspensky } \\
\text { medium/ } \\
24 \mathrm{~h}\end{array}$ & photosynthesis & $\begin{array}{c}\text { delayed } \\
\text { fluorescence } \\
\text { induction curves }\end{array}$ & [19] \\
\hline & $\begin{array}{l}\text { polyacrylate/ } \\
5\end{array}$ & $0-100 \mu \mathrm{g} \mathrm{L}^{-1}$ & $\begin{array}{l}4 \times \text { diluted TAP } \\
\text { medium } / \\
60 \mathrm{~min}\end{array}$ & transcriptome & $\begin{array}{c}\text { increased } \\
\text { expression of } \\
\text { transcript for } \\
\text { copper transport } \\
\text { protein } 2\end{array}$ & [30] \\
\hline
\end{tabular}


Table 1. Cont.

\begin{tabular}{|c|c|c|c|c|c|c|}
\hline $\begin{array}{l}\text { Algae } \\
\text { Species }\end{array}$ & $\begin{array}{l}\text { AgNP Coating/ } \\
\text { size (nm) }\end{array}$ & $\begin{array}{c}\text { AgNP } \\
\text { Concentration }\end{array}$ & $\begin{array}{c}\text { Exposure } \\
\text { Medium/Duration }\end{array}$ & $\begin{array}{l}\text { Investigated } \\
\text { Parameters }\end{array}$ & Findings & Reference \\
\hline & $\begin{array}{l}\text { PEG/ } \\
20\end{array}$ & $0.001-2200 \mu \mathrm{g} \mathrm{L}^{-1}$ & $\begin{array}{l}\text { Woods Hole MBL } \\
\text { medium/ } \\
72 \mathrm{~h}\end{array}$ & protein expression & $\begin{array}{l}\text { majority of the } \\
\text { proteins } \\
\text { with differential } \\
\text { expression were } \\
\text { upregulated, the } \\
\text { majority of } \\
\text { which were } \\
\text { those involved } \\
\text { in thiamine } \\
\text { biosynthesis, } \\
\text { Calvin cycle, and } \\
\text { photosynthesis }\end{array}$ & [28] \\
\hline & $\begin{array}{c}\text { carbonate/40 } \pm 0.5 \\
\text { chitosan/25 } \pm 1.7 \\
\text { citrate/ } 17 \pm 0.9 \\
\text { dexpanthenol/ } \\
456 \pm 200 \\
\text { gelatin/52 } \pm 2.8 \\
\text { lactate/ } 35 \pm 14.8 \\
\text { NDB } / 45 \pm 3.3 \\
\mathrm{PEG} / 70 \pm 8.3 \\
\mathrm{PVP} / 84 \pm 40.0\end{array}$ & $0-1000 \mu \mathrm{mol} \mathrm{L}-1$ & $\begin{array}{c}10 \mathrm{mmol} \mathrm{L}^{-1} \\
\text { MOPS/ } \\
1 \text { and } 2 \mathrm{~h}\end{array}$ & photosynthesis & $\begin{array}{l}\text { toxicity was } \\
\text { related neither to } \\
\text { particle size nor } \\
\text { to the coatings }\end{array}$ & {$[20]$} \\
\hline & $\begin{array}{c}\text { PVP/ } \\
11.7 \pm 1.9\end{array}$ & 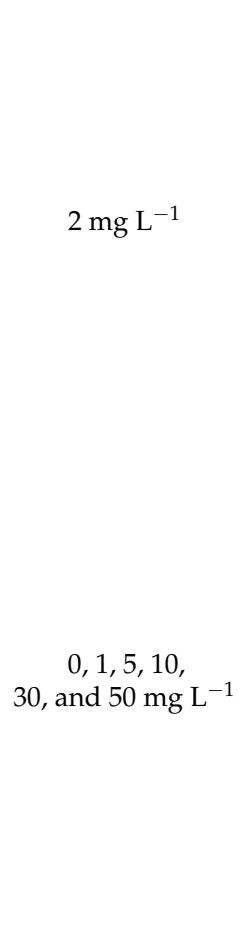 & $\begin{array}{c}\text { tris-acetate- } \\
\text { phosphate/ } \\
4,12,24,36 \text {, and } \\
48 \mathrm{~h} \\
\\
\\
\text { SE medium/ } \\
24,48, \\
72,96, \text { and } \\
120 \mathrm{~h}\end{array}$ & $\begin{array}{l}\text { AgNP uptake, } \\
\text { distribution, and } \\
\text { morphology in } \\
\text { algal cells }\end{array}$ & $\begin{array}{l}\text { AgNPs enter the } \\
\text { periplasmic } \\
\text { space after } \\
\text { cellular } \\
\text { internalization } \\
\text { and } \\
\text { sequestration by } \\
\text { sulfidation of } \\
\text { Ag }^{+} \text {ions } \\
\text { released from } \\
\text { AgNPs by } \\
\text { thiolates and } \\
\text { sulfides } \\
\text { damaged } \\
\text { chloroplasts and } \\
\text { inhibited } \\
\text { photosynthetic } \\
\text { pigments } \\
\text { synthesis; } \\
\text { inhibited } \\
\text { growth; } \\
\text { increased ROS } \\
\text { production } \\
\text { and MDA } \\
\text { content; } \\
\text { activated } \\
\text { antioxidant } \\
\text { enzymes }\end{array}$ & {$[31]$} \\
\hline Chlorella vulgaris & $\begin{array}{l}\text { uncoated/ } \\
50\end{array}$ & $\begin{array}{l}0.1,1, \text { and } \\
10 \mathrm{mg} \mathrm{L}^{-1}\end{array}$ & $\begin{array}{l}\text { BG-11 medium/ } \\
24 \mathrm{~h}\end{array}$ & $\begin{array}{l}\text { viability; oxidative } \\
\text { stress }\end{array}$ & $\begin{array}{l}\text { strong decrease } \\
\text { in chlorophyll } \\
\text { content and cell } \\
\text { viability; } \\
\text { increased ROS } \\
\text { formation and } \\
\text { lipid } \\
\text { peroxidation }\end{array}$ & [32] \\
\hline
\end{tabular}


Table 1. Cont.

\begin{tabular}{|c|c|c|c|c|c|c|}
\hline $\begin{array}{l}\text { Algae } \\
\text { Species }\end{array}$ & $\begin{array}{l}\text { AgNP Coating/ } \\
\text { size }(\mathrm{nm})\end{array}$ & $\begin{array}{c}\text { AgNP } \\
\text { Concentration }\end{array}$ & $\begin{array}{c}\text { Exposure } \\
\text { Medium/Duration }\end{array}$ & $\begin{array}{l}\text { Investigated } \\
\text { Parameters }\end{array}$ & Findings & Reference \\
\hline & $\begin{array}{l}\text { citrate/10 } \\
\text { PVP/10 } \\
\text { PEG/10 }\end{array}$ & $\begin{array}{l}\text { AgNP-citrate-9- } \\
140 \text { nmol L } \\
\text { AgNP-PEG- } \\
\text { 28-935 nmol L-1 } \\
\text { AgNP-PVP- } \\
28-93 \text { nmol L }^{-1}\end{array}$ & $\begin{array}{c}\text { Jaworski's } \\
\text { medium/ } 72 \mathrm{~h}\end{array}$ & $\begin{array}{c}\text { growth; } \\
\text { chlorophyll } \\
\text { content; AgNP } \\
\text { accumulation }\end{array}$ & $\begin{array}{l}\text { citrate- and } \\
\text { PVP-coated } \\
\text { AgNPs showed } \\
\text { similar uptake } \\
\text { rate and toxicity; } \\
\text { AgNP-PEG had } \\
\text { the highest } \\
\text { uptake rate but } \\
\text { the lowest } \\
\text { toxicity }\end{array}$ & [33] \\
\hline & $\begin{array}{l}\text { citrate/ } \\
9-10\end{array}$ & $\begin{array}{c}9.3,93 \\
463, \text { and } 926 \\
\text { nmol L }^{-1}\end{array}$ & $\begin{array}{l}\text { BG-11 medium/ } \\
24,48,72 \text {, and } 96 \mathrm{~h}\end{array}$ & $\begin{array}{l}\text { oxidative stress; } \\
\text { gene and protein } \\
\text { expression }\end{array}$ & $\begin{array}{l}\text { induction of } \\
\text { antioxidant } \\
\text { enzymes, } \\
\text { unabated } \\
\text { photosynthesis } \\
\text { at growth- } \\
\text { inhibitory AgNP } \\
\text { concentration }\end{array}$ & [21] \\
\hline & $\begin{array}{l}\text { uncoated/ } \\
50 \text { and } 100\end{array}$ & $\begin{array}{c}10,50, \\
100, \text { and } \\
200 \mathrm{mg} \mathrm{L}^{-1}\end{array}$ & $\begin{array}{c}\mathrm{f} / 2 \text { medium/ } \\
24,48,72 \text {, and } 96 \mathrm{~h}\end{array}$ & $\begin{array}{l}\text { cell viability, } \\
\text { chlorophyll } a \\
\text { concentration, } \\
\text { ROS formation }\end{array}$ & $\begin{array}{l}\text { negative effect } \\
\text { on cell viability } \\
\text { and chlorophyll } \\
a \text { content; } \\
\text { increased ROS } \\
\text { formation }\end{array}$ & [34] \\
\hline & $\begin{array}{l}\text { glucose/ } \\
20 \pm 5\end{array}$ & $\begin{array}{c}0.1,1,10, \\
100 \mu \mathrm{g} \mathrm{L}^{-1} \\
\text { and } 1 \mathrm{mg} \mathrm{L}^{-1}\end{array}$ & $\begin{array}{l}\text { BBM/ } \\
24 \mathrm{~h} \text { and } \\
1 \text { week }\end{array}$ & $\begin{array}{c}\text { growth, } \\
\text { chlorophyll } a \\
\text { content, AgNP } \\
\text { biodistribution, } \\
\text { and subcellular } \\
\text { localization }\end{array}$ & $\begin{array}{c}\text { exposure time } \\
\text { and } \\
\text { dose-dependent } \\
\text { growth } \\
\text { reduction and } \\
\text { decrease in } \\
\text { chlorophyll } a \\
\text { content; } \\
\text { internalized } \\
\text { AgNPs inside } \\
\text { large vacuoles }\end{array}$ & [35] \\
\hline & $\begin{array}{l}\text { citrate/24, } \\
\mathrm{PEI} / 29\end{array}$ & $\begin{array}{c}\text { AgNP-citrate -; } \\
71.2 \pm 13.6 \mu \mathrm{g} \mathrm{L}^{-1} \\
\text { AgNP-PEI -; } \\
51.6 \pm 9.6 \mu \mathrm{g} \mathrm{L}^{-1}\end{array}$ & $\begin{array}{l}\text { BG-11 medium/ } \\
24 \mathrm{~h}\end{array}$ & protein expression & $\begin{array}{l}\text { AgNP-coating } \\
\text { electrical } \\
\text { property- } \\
\text { dependent } \\
\text { effects: negative } \\
\text { AgNP-citrate } \\
\text { regulated } \\
\text { mitochondrial } \\
\text { function-related } \\
\text { proteins; } \\
\text { positive } \\
\text { AgNP-PEI } \\
\text { targeted } \\
\text { ribosome } \\
\text { function-related } \\
\text { proteins and } \\
\text { interrupted } \\
\text { pathways of } \\
\text { protein synthesis } \\
\text { and DNA } \\
\text { genetic } \\
\text { information } \\
\text { transmission }\end{array}$ & [29] \\
\hline
\end{tabular}


Table 1. Cont.

\begin{tabular}{|c|c|c|c|c|c|c|}
\hline $\begin{array}{l}\text { Algae } \\
\text { Species }\end{array}$ & $\begin{array}{l}\text { AgNP Coating/ } \\
\text { size }(\mathrm{nm})\end{array}$ & $\begin{array}{c}\text { AgNP } \\
\text { Concentration }\end{array}$ & $\begin{array}{c}\text { Exposure } \\
\text { Medium/Duration }\end{array}$ & $\begin{array}{l}\text { Investigated } \\
\text { Parameters }\end{array}$ & Findings & Reference \\
\hline & $\begin{array}{c}\text { citrate/ } \\
46.8 \pm 3.3\end{array}$ & $\begin{array}{c}\text { 90, 180, } \\
360,720, \\
\text { and } 1440 \mu \mathrm{g} \mathrm{L}^{-1}\end{array}$ & $\begin{array}{l}\text { BBM/ } \\
24,48,72, \\
\text { and } 96 \mathrm{~h}\end{array}$ & $\begin{array}{l}\text { growth rate, cell } \\
\text { diameter and } \\
\text { volume; } \\
\text { chlorophyll } a \\
\text { and } b \text {, } \\
\text { content of } \\
\text { pheophytin, } \\
\text { carotenoids } \\
\text { carbohydrate, total } \\
\text { lipids and proteins }\end{array}$ & $\begin{array}{l}\text { altered growth } \\
\text { kinetics and cell } \\
\text { metabolism } \\
\text { expressed in } \\
\text { photosynthetic } \\
\text { pigments and } \\
\text { biochemical } \\
\text { composition }\end{array}$ & [22] \\
\hline \multirow[t]{6}{*}{$\begin{array}{l}\text { Raphidocelis } \\
\text { subcapitata }\end{array}$} & PVP/96 & $\begin{array}{c}\mathrm{EC} 50=9.9 \\
{[7.4-13.2] \mu \mathrm{g} \mathrm{L}^{-1}}\end{array}$ & $\begin{array}{l}\text { BBM/ } \\
96 \mathrm{~h}\end{array}$ & acute toxicity & $\begin{array}{l}\text { AgNP-dose } \\
\text { dependent } \\
\text { toxicity }\end{array}$ & [36] \\
\hline & $\begin{array}{c}\text { citrate } / 14 \\
\text { PVP /15 } \\
\text { micron } / 2000-3500\end{array}$ & $\begin{array}{c}\text { AgNP-citrate - } \\
3.0 \pm 0.7 \mu g \mathrm{~L}^{-1} \\
\text { AgNP-PVP - } \\
19.5 \pm 6.1 \mu \mathrm{g} \mathrm{L}^{-1} \\
\text { micron - } \\
966 \mu \mathrm{g} \mathrm{L}^{-1}\end{array}$ & $\begin{array}{l}\text { modified USEPA } \\
\text { medium/ } 72 \mathrm{~h}\end{array}$ & $\begin{array}{l}\text { growth rate } \\
\text { inhibition }\end{array}$ & $\begin{array}{l}\text { AgNP-citrate } \\
\text { was found to be } \\
\text { more toxic than } \\
\text { AgNP-PVP; } \\
\text { micron-sized } \\
\text { particles were } \\
\text { less toxic than } \\
\text { AgNPs; presence } \\
\text { of natural } \\
\text { organic matter } \\
\text { stabilized } \\
\text { AgNPs and } \\
\text { reduced toxicity } \\
\text { in freshwater }\end{array}$ & [37] \\
\hline & $\begin{array}{l}\text { alkane material/ } \\
\qquad 3-8\end{array}$ & 15 and $30 \mu \mathrm{g} \mathrm{L}^{-1}$ & $\begin{array}{l}\text { MBL medium/ } \\
48 \mathrm{~h}\end{array}$ & $\begin{array}{l}\text { kinetics of uptake } \\
\text { and elimination of } \\
\text { AgNP in } \\
\text { comparison to } \\
\mathrm{AgNO}_{3}\end{array}$ & $\begin{array}{l}\text { AgNP were not } \\
\text { able to penetrate } \\
\text { the cells, and Ag } \\
\text { accumulation } \\
\text { happens through } \\
\text { the uptake of Ag } \\
\text { ions }\end{array}$ & [38] \\
\hline & $\begin{array}{l}\text { PVP/ } \\
20\end{array}$ & $\begin{array}{l}0.1 \text { to } 1000 \\
\mu \mathrm{mol} \mathrm{L}^{-1}\end{array}$ & $\begin{array}{c}1.36 \mathrm{mmol} \mathrm{L}^{-1} \\
\mathrm{Ca}\left(\mathrm{NO}_{3}\right)_{2 \prime} \\
0.73 \mathrm{mmol} \mathrm{L}^{-1} \\
\mathrm{Mg}\left(\mathrm{NO}_{3}\right)_{2,} \\
1.19 \mathrm{mmol} \mathrm{L}^{-1} \\
\mathrm{NaNO}_{3}, \\
0.20 \mathrm{mmol} \mathrm{L}^{-1} \\
\mathrm{KNO}_{3} \text { in sterile } \\
\mathrm{Milli}-\mathrm{Q} \text { water } / \\
4.5 \mathrm{~h}\end{array}$ & $\begin{array}{c}\text { photosynthetic } \\
\text { efficiency }\end{array}$ & $\begin{array}{c}\text { inhibited } \\
\text { photosynthetic } \\
\text { efficiency; humic } \\
\text { substances } \\
\text { alleviated } \\
\text { AgNP-imposed } \\
\text { toxicity in a } \\
\text { dose-dependent } \\
\text { matter }\end{array}$ & [23] \\
\hline & $\begin{array}{c}\text { uncoated/ } \\
\text { NM300K-16 } \pm 5 \\
\text { NM302-176 } \pm 41 \\
\text { M-AgNP-11 } \pm 3\end{array}$ & 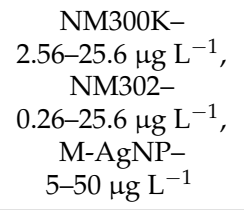 & $\begin{array}{l}\text { modified OCED } \\
\text { medium without } \\
\text { Fe-EDTA/ } \\
72 \mathrm{~h}\end{array}$ & growth & $\begin{array}{l}\text { reduced growth } \\
\text { in the following } \\
\text { order } \\
\text { M-AgNP > } \\
\text { NM300K > } \\
\text { NM302 }\end{array}$ & [24] \\
\hline & $\begin{array}{c}\text { tyrosine/ } \\
0.56 \pm 2.27 \\
\text { epigallocatechin/ } \\
9.27 \pm 1.29 \\
\text { curcumin/ } \\
13.68 \pm 0.76\end{array}$ & $\begin{array}{c}0.020,0.050,0.080 \\
0.110,0.140,0.170 \\
0.200, \text { and } \\
0.230 \mathrm{mg} \mathrm{L}^{-1}\end{array}$ & $\begin{array}{l}\text { MLA medium/ } \\
24,48 \text {, and } 72 \mathrm{~h}\end{array}$ & $\begin{array}{c}\text { growth, } \\
\text { antioxidant } \\
\text { enzyme activities }\end{array}$ & $\begin{array}{l}\text { physicochemical } \\
\text { characteristics of } \\
\text { the AgNP surface } \\
\text { coating plays a } \\
\text { major role in } \\
\text { determining } \\
\text { AgNP behavior } \\
\text { in growth } \\
\text { medium, toxicity, } \\
\text { bioaccumulation, } \\
\text { and antioxidant } \\
\text { enzyme } \\
\text { responses } \\
\text { of algae }\end{array}$ & [25] \\
\hline
\end{tabular}


Table 1. Cont.

\begin{tabular}{|c|c|c|c|c|c|c|}
\hline $\begin{array}{l}\text { Algae } \\
\text { Species }\end{array}$ & $\begin{array}{l}\text { AgNP Coating/ } \\
\text { size }(\mathrm{nm})\end{array}$ & $\begin{array}{c}\text { AgNP } \\
\text { Concentration }\end{array}$ & $\begin{array}{c}\text { Exposure } \\
\text { Medium/Duration }\end{array}$ & $\begin{array}{l}\text { Investigated } \\
\text { Parameters }\end{array}$ & Findings & Reference \\
\hline \multirow[t]{2}{*}{ Euglena gracilis } & citrate/47 & $\begin{array}{l}0-40 \mu \mathrm{mol} \mathrm{L} \mathrm{L}^{-1} \text { for } \\
\text { photosynthesis } \\
5 \mu \mathrm{mol} \mathrm{L}{ }^{-1} \text { for cell } \\
\text { morphology } \\
0-10 \mu \mathrm{mol} \mathrm{L}^{-1} \text { for } \\
\text { uptake }\end{array}$ & $\begin{array}{c}10 \mathrm{mmol} \mathrm{L}^{-1} \\
\text { MOPS/ } \\
1 \text { and } 2 \mathrm{~h} \text { for } \\
\text { photosynthesis } \\
1 \mathrm{~h} \text { for cell } \\
\text { morphology and } \\
\text { uptake }\end{array}$ & $\begin{array}{c}\text { photosynthetic } \\
\text { yield } \\
\text { cell morphology }\end{array}$ & $\begin{array}{c}\text { photosynthetic } \\
\text { yield decreased } \\
\text { in a } \\
\text { concentration- } \\
\text { dependent } \\
\text { manner; cell } \\
\text { morphology was } \\
\text { significantly } \\
\text { altered: } \\
\text { increased uptake } \\
\text { with increasing } \\
\text { AgNP } \\
\text { concentration up } \\
\text { to } 2.5 \mu \text { mol L } \\
\text { AgNPs }\end{array}$ & [39] \\
\hline & $\begin{array}{l}\text { citrate/ } \\
38-73\end{array}$ & $0-40 \mu \mathrm{mol} \mathrm{L}{ }^{-1}$ & $\begin{array}{l}\text { MOPS/ } \\
1 \text { and } 2 \mathrm{~h}\end{array}$ & $\begin{array}{c}\text { silver uptake, } \\
\text { photosynthetic } \\
\text { yield }\end{array}$ & $\begin{array}{l}\text { AgNPs adsorb } \\
\text { onto the cell } \\
\text { surface and can } \\
\text { bind } \\
\text { extracellular } \\
\text { proteins }\end{array}$ & [40] \\
\hline Pithophora oedogonia & $\begin{array}{l}\text { uncoated/ } \\
10 \text { to } 15\end{array}$ & 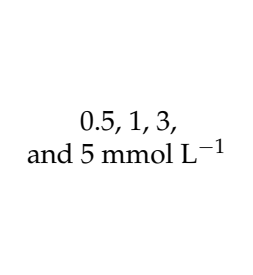 & $\begin{array}{c}\mathrm{BBM} / \\
5,7 \text {, and } 10 \text { days }\end{array}$ & $\begin{array}{l}\text { chlorophyll } \\
\text { content, } \\
\text { chromosomal } \\
\text { aberrations }\end{array}$ & $\begin{array}{c}\text { cell wall } \\
\text { rupture and } \\
\text { degradation, } \\
\text { reduction in } \\
\text { total chlorophyll } \\
\text { content, } \\
\text { cytological } \\
\text { abnormalities }\end{array}$ & [27] \\
\hline Chara vulgaris & $\begin{array}{l}\text { uncoated/ } \\
10 \text { to } 15\end{array}$ & $\begin{array}{c}0.5,1,3, \\
\text { and } 5 \mathrm{mmol} \mathrm{L}^{-1}\end{array}$ & $\begin{array}{c}\text { BBM/ } \\
5,7 \text {, and } 10 \text { days }\end{array}$ & $\begin{array}{l}\text { chlorophyll } \\
\text { content, } \\
\text { chromosomal } \\
\text { aberrations }\end{array}$ & $\begin{array}{c}\text { reduction in } \\
\text { total chlorophyll } \\
\text { content, } \\
\text { cytological } \\
\text { abnormalities } \\
\text { with disturbed } \\
\text { metaphase }\end{array}$ & [27] \\
\hline Scenedesmus sp. & $\begin{array}{l}\text { PVA/ } \\
6 \text { to } 10\end{array}$ & $\begin{array}{l}\text { 5, 20,50,100, } \\
\text { and } 200 \mu \mathrm{g} \mathrm{L}^{-1}\end{array}$ & $\begin{array}{l}\text { COMBO medium/ } \\
72 \mathrm{~h}\end{array}$ & $\begin{array}{l}\text { growth, } \\
\text { chlorophyll } a \\
\text { concentration, } \\
\text { total lipids }\end{array}$ & $\begin{array}{l}\text { change in cell } \\
\text { diameter, } \\
\text { reduction in } \\
\text { chlorophyll } a \\
\text { content, } \\
\text { enhancement of } \\
\text { total lipid } \\
\text { production }\end{array}$ & [26] \\
\hline Chlorella pyrenoidosa & $\begin{array}{c}\text { citrate } / 19.3 \pm 6.3 \\
\mathrm{PVP} / 22.0 \pm 6.1\end{array}$ & $10 \mathrm{mg} \mathrm{L}^{-1}$ & $\begin{array}{l}\text { OECD medium/ } \\
\text { various exposure } \\
\text { times }(0-24 \mathrm{~h})\end{array}$ & $\begin{array}{l}\text { growth inhibition, } \\
\text { bioaccumulation, } \\
\text { interaction } \\
\text { between EPS and } \\
\text { AgNPs }\end{array}$ & $\begin{array}{l}\text { AgNP-PVP } \\
\text { strongly bind to } \\
\text { EPS and have } \\
\text { lower uptake } \\
\text { and toxicity } \\
\text { compared to } \\
\text { AgNP-citrate; } \\
\text { removal of EPS } \\
\text { increases Ag } \\
\text { uptake for both } \\
\text { AgNP-PVP and } \\
\text { AgNP-citrate }\end{array}$ & [41] \\
\hline
\end{tabular}

In studies dealing with phytotoxicity of AgNPs, different types of coating agents were used for AgNP stabilization. The PubMed search performed for this review resulted in 16 different coatings used in the assessment of AgNP toxic effects in both plants and freshwater green algae (Figure 1). AgNP stabilization is usually obtained by either steric stabilization, which arises as a consequence of polymer adsorption onto the surface of 
particles [42], or electrostatic stabilization, which includes surface charge development, usually by physical adsorption of charged species onto the surface [43]. Among nonionic polymer coatings, the most frequently used one is PVP, which has been applied in numerous investigations performed on plants [44-51] and algae [14,20,23]. Besides PVP, polyethylene glycol (PEG) and polyvinyl alcohol (PVA) have also been frequently used for AgNP stabilization in both plant [52-57] and algal research [19,20,26,28], while GA, a natural polymer consisting of polysaccharides and glycoproteins, has mostly been utilized in plant studies [10,46,58,59]. Considering the electrostatic stabilization of AgNPs, citrate is the most commonly applied coating that provides a negative charge, and it has been employed in many toxicology studies performed on both plants $[47,50,51,60-63]$ and algae [20-22,29,33,37,40,41,64]. On the other hand, positively charged AgNPs have been scarcely used in plant studies and were usually obtained by application of cationic surfactant CTAB [50,51,65], although didecyldimethylammonium bromide (DDAB) [66] or polyhexamethylene biguanide (PHMB) [67] have also been employed. Cationic polymer polyethyleneimine (PEI) was applied as AgNP coating in the study on freshwater algae C. vulgaris [29].
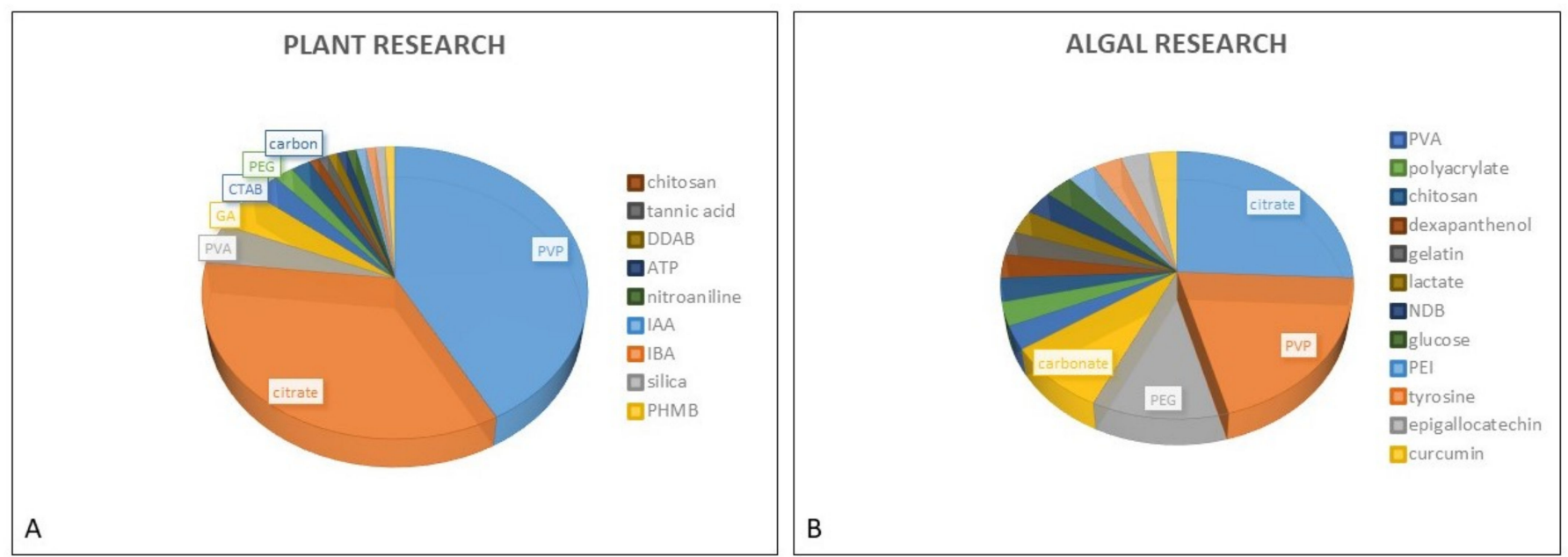

Figure 1. Proportional representation of coatings used for AgNP stabilization in plant (A) and algal (B) research.

In this paper, we attempt to give an overview on how employment of different stabilizing coatings can modulate AgNP-induced phytotoxicity with respect to growth, physiology, and gene and protein expression in terrestrial and aquatic plants and freshwater algae. Moreover, this is, to our knowledge, the first publication to summarize all aspects of AgNPs toxicity on freshwater algae.

\section{AgNP Stability in Various Exposure Media}

A thorough physicochemical characterization of AgNPs used for toxicological investigations is needed both prior and during the experiment, considering that different exposure conditions may affect their size, shape, and surface electric charge [68-70] and, consequently, alter their uptake, toxicokinetics, toxicodynamics, and biological fate $[69,71]$. Biological media have a high chemical complexity, which is determined by $\mathrm{pH}$, ionic strength, and various concentrations of dissolved organic and inorganic matter. Therefore, it is impossible to correctly predict the form (particulate or ionic) and dose of silver the system is exposed to [72] due to the interactions of AgNPs and the medium that can lead to both agglomeration/aggregation of nanoparticles and their dissolution [73-75]. On top of that, chemical or photo-induced reduction of $\mathrm{Ag}^{+}$ions released from the AgNP surface can lead to formation of secondary particles with different characteristics compared to the original ones $[70,76,77]$. Therefore, understanding AgNP dynamics in exposure 
medium used for plant and algae treatment plays a key role in interpretation of those toxicological studies.

Colloidal stability of AgNPs in different media used for plant and algal nanotoxicological studies is greatly determined by the composition of the medium itself and the exposure period of the treatment, as discussed in our previous publications [1,13]. Moreover, intrinsic properties of AgNPs (size, shape, and surface charge) also direct their behavior in the environment [11]. Generally, rate of dissolution is higher for smaller uncoated AgNPs in media rich in molecules that tend to complex released $\mathrm{Ag}^{+}$ions [78]. Indeed, plant experiments conducted with uncoated AgNPs revealed significantly higher agglomeration and dissolution rates of AgNPs in tested liquid media used for duckweed (Spirodela punctata) [79] and Arabidopsis thaliana treatment [80], or sand matrix employed in wheat (Triticum aestivum) experiments [81], compared to water treatment of broad bean (Vicia faba) [82], lettuce (Lactuca sativa), and cucumber (Cucumis sativus) [83]. In algal research, significant agglomeration of uncoated AgNPs was also measured in high salt medium (HSM) used for C. reinhardtii cultures [17] and BG-11 medium for C. vulgaris treatment [32]. Uncoated AgNPs have a negative surface charge due to the presence of hydroxo-, oxo-, or sulfide groups on the surface, which stabilizes them in deionized water. However, existence of counterions in the nutrient media and soil reduces repulsive forces between them and promotes aggregation [9].

Stabilization of AgNPs in a medium can be achieved using surface coatings designed to lower their surface energy, prevent interactions with the environment, and diminish aggregation rates [84,85]. Different routes for AgNP stabilization can be employed, depending on their final application [86]. Citrate, a small monomeric molecule [11,61,87], is commonly implemented as a stabilizer in research of AgNP effects on plants and algae. It provides a highly negative charge at the AgNP surface, ensuring their stabilization through electrostatic means. Stability measurements of citrate-coated AgNPs in water medium using dynamic light scattering (DLS) revealed no significant changes in their size and surface charge in moderately hard water applied for maize (Zea mays) and cabbage (Brassica oleracea) treatment [88]. On the contrary, changes in AgNP zeta potential connected with the loss of coating and higher dissolution rates in ultrapure water were reported in an experiment with tobacco (Nicotiana tabacum) plants [89]. Most of researchers found citrate-coated AgNPs highly unstable in different media with high ionic strength used for plant growth. Significant increase in hydrodynamic diameter, indicating AgNP agglomeration, was observed in liquid half- and full-strength Murashige and Skoog (MS) medium [51,60,90], 1/4 Hoagland medium [91], and in a nutrient solution prepared according to OECD 221 guidelines [62]. Decrease of zeta potential was also reported, indicating the loss of citrate coating [62,92]. Moreover, significant concentrations of $\mathrm{Ag}^{+}$ions were measured both in liquid nutrient media $[90,91,93]$ and in soil $[94,95]$, as a consequence of citrate-coated AgNP dissolution. However, addition of natural polymers, such as Phytagel, stabilized AgNP-citrate in a solid MS medium by encapsulation, which reduced their oxidative changes during exposure of tobacco seedlings $[60,61]$. On the other hand, AgNP-citrate seem to be quite stable in media used for cultivation of algae. No significant difference was obtained in size and zeta potential values in AgNP-citrate immersed in $10 \mathrm{mmol} \mathrm{L}^{-1} 3$-morpholinopropanesulfonic acid (MOPS) used for Euglena gracilis treatment [40], while only minor dissolution was found in BG-11 medium used for C. vulgaris [21]. Generally, electrostatically stabilized AgNPs have shown less media-induced modifications when lower ionic strength and higher $\mathrm{pH}$ values are applied $[7,96]$. This could explain their higher stability in algal treatment media compared to media used in plant research. Surfactant molecules, such as positively charged CTAB, are also used in plant AgNP research as electrostatic stabilizers. As with AgNP-citrate, the behavior of AgNP-CTAB changes depending on the medium used for plant treatment and similar trends were observed. AgNP-CTAB was shown to be quite stable in ultrapure water used for treatment of onion (Allium cepa) roots [65], but its addition in liquid 1/2 MS medium used for tobacco plants exposure led to rapid agglomeration observed by DLS measurements and transmission electron microscope (TEM) imaging. These 
findings were additionally corroborated by significant decrease of their zeta potential [51]. Interesting trend was observed with UV-VIS spectrometry in research by Biba et al. [50], where AgNP-CTAB showed good stability in a solid $1 / 2$ strength MS medium used for tobacco germination experiments. However, addition of cysteine, a strong silver ligand, led to rapid dissolution and release of $\mathrm{Ag}^{+}$, indicating a fast removal of surface coating and showing that CTAB is a relatively labile ligand.

The use of polymer coatings for AgNP stabilization provides a higher colloidal stability through steric repulsion between the polymer-coated particles $[50,87,97,98]$. The most frequently used polymer in plant and algal nanotoxicology research is PVP (Figure 1). High stability of PVP-coated AgNPs in plant research has been shown both in ultrapure water [65] and in various nutrient media used for plant growth. The size of PVP-coated AgNPs was found to be constant in 1/2 Hutner's solution employed for Landoltia punctata two-day treatment [99]. Similarly, Jiang et al. [100] reported that $10 \%$ Hoagland's solution used for Spirodela polyrhiza treatment had no effect on AgNP-PVP shape and size, although their later research indicated a slight change in AgNP-PVP zeta potential in the aforementioned medium [46]. Yang et al. [101,102] have examined how different environmental factors affect AgNP-PVP stability in media commonly used for growth of rice (Oriza sativa). Their results showed that chloride ions, which play an important role in uptake and accumulation of environmental silver (both particulate and ionic), significantly increase AgNP-PVP stability in Hewitt medium by increasing the overall negative charge of NPs, thus enhancing their dispersion [101]. Furthermore, their later research proved AgNP-PVP to be stable in 1/15 Hewitt medium even after the addition of $\mathrm{Fe}^{2+}$-EDTA [102]. On the other hand, a couple of studies have demonstrated medium-induced alterations of PVP-stabilized AgNPs. Comparison of DLS results for citrate-, PVP- and CTAB-coated AgNPs in 1/2 strength MS medium used for tobacco treatment showed a slower agglomeration rate for AgNP-PVP compared to AgNP-citrate and AgNP-CTAB, which was also accompanied by the decrease of their zeta potential [51]. This finding indicated increased electrostatic repulsion between nanoparticles. In a similar study, AgNP-PVP were found to be less stable and prone to dissolution in the solid 1/2 MS medium in comparison to AgNP-CTAB [50]. On top of that, addition of cysteine led to their rapid agglomeration coupled with additional dissolution and formation of silver clusters from dissolved $\mathrm{Ag}^{+}$[50]. Stabilization of AgNPs by another type of steric molecule, GA, successfully protected AgNPs against aggregation and dissolution in ultrapure water used for treatment of Italian ryegrass (Lolium multiflorum) [10], and in 10\% Hoagland medium used for exposure of $S$. polyrhiza $[58,100]$. Similar stabilizing capabilities were also observed for PEG-coated AgNPs that exhibited no significant changes in size in $1 / 4$ Hoagland medium during $A$. thaliana treatment [52]. Stability of polymer-coated AgNPs was also examined in algal research. PEG-, PVP-, and chitosan-coated AgNPs retained the same size and charge in MOPS used for $C$. reinhardtii treatment even after cysteine addition, confirming their excellent stabilization against dissolution in the medium [20]. On the other hand, in a medium used for R. subcapitata cultivation and treatment, AgNP-PVP showed high agglomeration rate that was mitigated with the addition of a commercial humic substance, which provided electrostatic repulsive forces and decreased their zeta potential [23]. When three organic ligands with different numbers of phenol structures were used as AgNP coatings in toxicological studies on algae $R$. subcapitata, differences in their stability were observed in the Elendt M4 medium used for algal growth [25]. The highest rate of aggregation was obtained with tyrosine-AgNPs, followed by epigallocatechin gallate-AgNPs, while curcumin-coated AgNPs showed no signs of aggregation. Observed differences were attributed to different coating materials [25], proving that thorough characterization and stability analyses are imperative for accurate interpretation of nanotoxicological data.

All these findings show that AgNP behavior in the nutrient media is far from predictable. This becomes even more complicated when plants or algae are added to the media. Interaction of AgNPs with the biomolecules present in biological environment (nucleic acids, proteins, lipids, etc.) can lead to the formation of the surface corona $[70,83]$ that can 
reverse AgNP surface charge [103]. These processes can either stabilize AgNPs or result in their increased aggregation and dissolution rates, depending on the AgNP intrinsic characteristics $[73,97]$. However, information on the AgNP corona formation in plant and algae is scarce due to the lack of published studies. Considering the emerging interest in application of nanotechnology in the agriculture [104], AgNP modifications due to the surface corona formation should be a focus of any future nanotoxicological studies.

\section{Silver Uptake and Effects on Growth and Morphology}

Seed germination represents the first and the most crucial step for plant growth and the overall crop yield [105]. It is the most sensitive stage of plant ontogenesis, heavily susceptible to various environmental factors, such as AgNP exposure, that can modulate metabolic processes during germination and ultimately affect plant growth [106]. To assess AgNP effects on seed germination and early growth, most of the conducted studies examined germination percentage and rate, root, and shoot elongation, plant morphology, and changes in biomass $[1,50,60,107]$. Results showed both positive and negative effects, depending on the plant species, exposure method, and characteristics of AgNPs (reviewed in Tkalec et al. [1]). Another important factor determining AgNP phytotoxic effects is their uptake. The main route of AgNPs entry into the plant cell occurs through the pores in the cell wall $[74,108]$. Their further translocation occurs by endocytosis and through plasmodesmata $[109,110]$. AgNP movement and effects are highly dependent on the plant growth stage. If taken up by roots of seedlings or adult plants, AgNPs can penetrate the vascular tissue and reach the stems and leaves (Figure 2), where they can cause further damage [111]. If AgNPs enter the seeds during imbibition period, they can move to embryonic cells and in that way cause long-term effects for the plant [112]. Properties of AgNPs are determined mostly by their size and surface coating that play an important role in AgNP uptake and modulate their effects on germination and development.

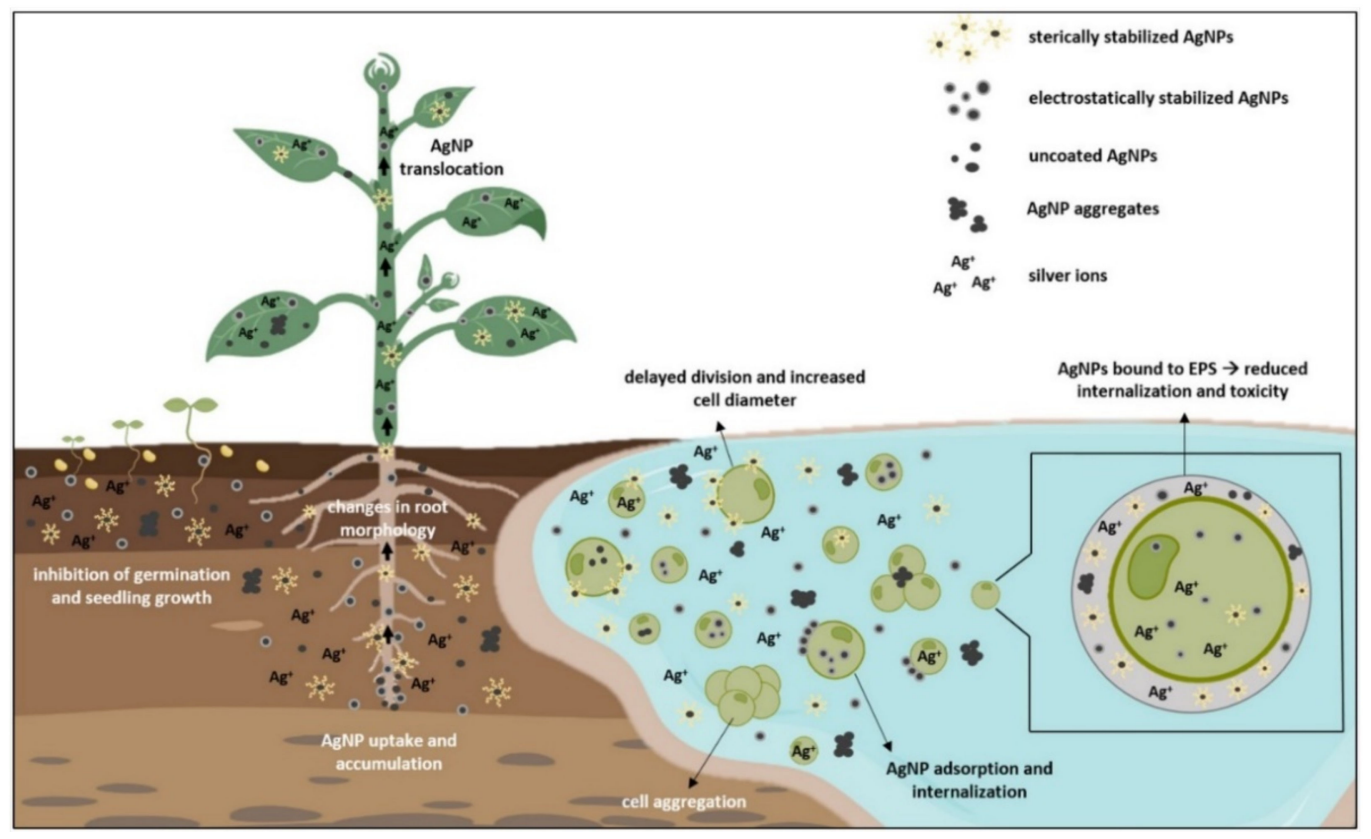

Figure 2. Uptake of differently coated and uncoated AgNPs in plants and freshwater algae and their effects on growth and morphology. EPS-extracellular polymeric substances. Figure was created with BioRender.com. Accessed on 24 November 2021.

Electrostatically stabilized citrate-coated AgNPs showed higher potential for mediuminduced modifications, consequently leading to their pronounced phytotoxic effects. In a study by Pokhrel et al. [88], it was reported that AgNP-citrate significantly inhibited seed germination of cabbage and maize, but the effects on root elongation were found to 
be species-dependent. AgNP-citrate had no effect on maize root growth, but it inhibited growth of cabbage roots. Authors attributed this variance in results to the different size of seeds in question because smaller cabbage seeds with greater surface-to-volume ratio were found to be more prone to interaction with AgNPs [88]. Germination of tobacco seeds was also delayed and slower during the treatments with citrate-coated AgNPs, but effects on the seedling growth were shown to be concentration-dependent [60]. Root growth was enhanced at lower tested concentrations but significantly reduced at higher concentrations. In tomato (Lycopersicon esculentum) plants, citrate-coated AgNPs- had no effect on germination, but they significantly decreased root elongation, even in the lowest tested dose [113]. Adverse toxic effects of AgNP-citrate on growth of mung bean (Phaseolus radiatus) and great millet (Sorghum bicolor) were also reported [95]. AgNPs caused necrosis and browning of the root tissue of both plant species that was consequently attributed to accumulated AgNPs in the cells, as confirmed by TEM and X-ray energy dispersion spectroscopy (EDS). An interesting finding was obtained in the research by Geisler-Lee et al. [114], where no initial effects on germination of $A$. thaliana were detected upon exposure to citrate-coated AgNPs; however, negative effects were confirmed and amplified over the next three generations.

Effects of sterically stabilized AgNP-PVP on germination and plant early growth are also adverse. Scherer et al. [115] observed AgNP-PVP internalization in roots of $A$. cepa that led to reduction of germination index and root elongation. A study conducted on wheat seedlings showed that AgNP-PVP negatively impacted root length and fresh mass upon treatment, even though germination percentage and germination rate were not affected [45]. Furthermore, silver content was higher in roots compared to the leaves of treated seedlings. However, TEM images could not confirm AgNP entry to the cells and observed root tip browning was ascribed to AgNPs adsorbed to the root tissue [45]. Different trends were observed in rocket (Eruca sativa) seeds; germination of the seed was also not affected upon treatment with AgNP-PVP, but root growth was significantly stimulated [116]. Another study showed similar silver uptake for castor bean (Ricinus communis) seedlings exposed to AgNP-PVP and $\mathrm{AgNO}_{3}$. However, AgNP-PVP had no significant impact on castor bean seed germination and growth, while ionic silver significantly decreased those parameters [117]. In contrast, in the research of Wang et al. [118], in which AgNP-PVP was localized in the cell wall and intercellular spaces of $A$. thaliana roots, it was found that AgNPs promoted root growth at low concentrations. However, higher concentrations had the opposite effect, suggesting a dose-dependent response. Another hydrophilic molecule used in AgNP stabilization is PVA, which showed detrimental impact on growth and morphology of L. punctata with distinct signs of chlorosis [57]. Similar effects were reported for O. sativa, where higher doses induced AgNP-PVA penetration through the cell wall. Moreover, restricted root growth, decrease in dry weight, and significant damage of the cell morphology were revealed [55]. GA is another commonly used steric AgNP stabilizer. Yin et al. [10] found that AgNP-GA inhibited growth of L. multiflorum seedlings and significantly changed their root morphology, mainly observed as a lack of root hairs and damaged epidermis and root cap. These results were ascribed to high silver content measured in both roots and shoots of the seedlings. Moreover, detrimental effects of AgNP-GA were not mitigated with the addition of cysteine and were far more pronounced than the effects of ionic silver applied at same concentrations [10].

Only a couple of research groups compared differently coated AgNPs in the same experimental setup in an attempt to deduce the impact of a particular stabilizing agent (reviewed in [13]). Treatment with AgNP-GA generated deleterious results in germination and early growth of eleven wetland plants, which was not observed upon AgNP-PVP exposure [119]. These findings, however, cannot be assigned completely to the coating molecule, since applied AgNPs had different sizes $(20 \mathrm{~nm}$ for AgNP-PVP and $6 \mathrm{~nm}$ for AgNP-GA). Pereira et al. [120] reported that AgNP-PVP and AgNP-citrate caused harmful effects on Lemna minor upon treatment, but their mechanisms differed; AgNP-PVP affected growth rate, while AgNP-citrate induced chlorosis. Comparison of effects of 
uncoated AgNPs, AgNP-PVP, and AgNP-citrate on two developmental stages of bryophyte Physcomitrella patens revealed higher growth inhibition of protonema and leafy gametophyte in AgNP-citrate treatment compared to AgNP-PVP [121]. Discrepancy in effects between two developmental stages was found among the treatments with uncoated and citrate-coated AgNPs, i.e., uncoated AgNPs had higher impact on protonemal stage, while AgNP-citrate affected gametophyte stage more, which correlated with a significantly higher Ag uptake in the gametophyte tissue. This was attributed to higher rates of AgNP-citrate dissolution in the used medium over time [121]. In research conducted on tobacco seedlings, uptake of silver was similar for PVP- and CTAB-coated AgNPs and $\mathrm{AgNO}_{3}$ [50]. However, germination tests and measurements of root length and fresh and dry weight revealed significantly higher toxicity of AgNP-CTAB compared to AgNP-PVP and even ionic silver. Furthermore, harmful effects of AgNP-CTAB were not reduced with the addition of cysteine, and treatment with CTAB alone exhibited similar results. This finding suggests that phytotoxicity of CTAB-coated AgNPs originates from the coating itself. Similar discovery was reported in a study of AgNP-PVP and AgNP-DDAB effects on pea (Pisum sativum), where higher doses of AgNP-DDAB and treatment with DDAB itself significantly reduced seed germination and root length, which was not observed in AgNP-PVP treatment [65]. Presented results show differential response of plants during their early development in regard to coatings used in AgNP treatment. To better understand the mechanism of AgNP phytotoxicity, it is imperative to include more coating-dependent studies in the future.

Algal accumulation of AgNPs is an important process of AgNP transport through the aquatic ecosystem [122]. AgNPs can be adsorbed onto the algae surface and/or internalized in the cell due to the porous structure of the cell wall [6,122]. At normal conditions, only particles smaller than $20 \mathrm{~nm}$ can enter the algal cell, but during cell division and stress induction, cell wall permeability increases, allowing entry of even bigger sized particles (Figure 2), causing detrimental effects on their growth and morphology [33,123]. Uncoated AgNPs, which are highly unstable in a liquid medium, triggered significant cell aggregation and reduction of $C$. vulgaris viability [18,34]. The addition of different coatings changes AgNP characteristics and subsequently alter its uptake dynamics and overall effects. Citrate-coated AgNPs had no effect on growth of C. vulgaris [21] but significantly inhibited growth of Microcystis aeruginosa [21,124], showing differential effect of AgNPs on prokaryotic and eukaryotic algae. Romero et al. [22] reported increase in cell diameter and biomass in C. vulgaris upon exposure to AgNP-citrate that was attributed to their delayed division rate. Growth reduction was also observed in AgNP-citrate-treated E. gracilis, where further analysis showed that toxicity was not particle-specific but rather the combination of $\mathrm{Ag}^{+}$uptake and $\mathrm{AgNP}$ adsorption on the cell surface [40]. Upon exposure to PVP-coated AgNPs, growth of C. reinhardtii was not disturbed, even though AgNPs were found in the periplasmic space and cytoplasm. Furthermore, comparative experiments with $\mathrm{Ag}^{+}$exposure excluded the possibility of secondary AgNP formation inside the cell, suggesting AgNP entry into algal cell via cellular internalization [14]. On the contrary, IC50 values showed concentration dependent toxicity of AgNP-PVP in R. subcapitata (formerly known as Pseudokirchneriella subcapitata), which was significantly mitigated with the addition of humic substances that prevent AgNP dissolution [23]. Dose-dependent growth reduction was also measured in Scenedesmus sp. treated with AgNP-PVA [26]. A higher toxicity of AgNP-citrate compared to AgNP-PVP toward growth of $R$. subcapitata was ascribed to their different dissolution rates [26,36,37]. In a comparative study by Kalman et al. [33], AgNP-PVP and AgNP-citrate showed similar uptake rates and growth reduction in C. vulgaris, whereas AgNP-PEG treatment resulted in lower toxicity, even though its uptake was significantly faster. This effect could be attributed to the existence of extracellular polymeric substances (EPS), a protective layer on algae surface [41]. EPS can promote AgNP aggregation and complex $\mathrm{Ag}^{+}$, limiting overall AgNP bioavailability [125,126]. Moreover, EPS negative charge could be the reason for nonuniform algae response toward treatment with differently coated AgNPs [127]. Zhou et al. [41] have examined the role of EPS in Chlorella pyrenoidosa treated with AgNP-PVP 
and AgNP-citrate. Compared to AgNP-citrate, AgNP-PVP had lower cell internalization rate but higher adsorption constant. Further analyses revealed that AgNP-PVP strongly bind to EPS and have milder effect on plasmolysis and membranolysis than AgNP-citrate, whose highly negative charge limited adsorption onto the cell surface. Removal of EPS led to significant increase of AgNP internalization in both AgNP treatments, showing an important role of EPS in AgNP bioaccumulation. Since EPS evidently play an important role in bio-nano interactions, effects of differently coated AgNPs on EPS should be further investigated.

\section{Oxidative Stress Induction and Mobilization of Antioxidant Machinery}

Studies have shown that AgNPs are contributing to the production of reactive oxygen species (ROS) [128-130]. This can induce oxidative stress in plant and algal cells by combined effects of direct surface oxidation and ability of ROS species to react with important biomolecules (Figure 3), which, under severe oxidative stress, can even lead to the cell death [131]. Indirectly, release of $\mathrm{Ag}^{+}$ions from AgNPs [38,77,132,133] and properties of their coatings $[68,133,134]$ affect AgNP toxicity and additionally contribute to ROS production in promotion of oxidative stress. To elucidate if the extent of oxidative stress is related to AgNP stabilization by coating application, Souza et al. [135] have compared toxicity effects of uncoated and PVP-coated AgNPs on A. cepa. Results have demonstrated higher ROS production and more detrimental effects after treatment with uncoated when compared to PVP-coated AgNPs. To the best of our knowledge, such a comparative study on ROS induction in algae has not yet been published. Nonetheless, when C. vulgaris was exposed to uncoated AgNPs, a significant increase in ROS formation and lipid peroxidation was detected [32]. The observed effect was ascribed to AgNP-released $\mathrm{Ag}^{+}$ions, which can inhibit different antioxidant enzymes by binding to their essential functional thiol groups [136-138]. An independent study of Qian et al. [21] reported that there was no significant change in ROS content in C. vulgaris upon exposure to citrate-coated AgNPs. However, significantly increased ROS content and induced oxidative damage was recorded in $R$. subcapitata cells treated with AgNPs coated with L-tyrosine, curcumin, and epigallocatechin gallate [137]. The scarcity of data limits our knowledge on ROS induction upon exposure of algae to AgNPs. Therefore, it is still not clear how differently coated AgNPs influence formation of ROS as mediators of oxidative stress in the AgNP-induced cytotoxicity in algae.

On the other hand, multiple studies have evaluated the effect of electrostatically or sterically stabilized AgNPs on induction of oxidative stress in plants [10,21,55,100,120,139,140]. Nair and Chung [141] demonstrated that exposure to citrate-coated AgNPs led to a dosedependent increase of $\mathrm{H}_{2} \mathrm{O}_{2}$ content in shoots and roots of rice seedlings, while in situ accumulation of ROS was confirmed in root tips. Similarly, treatment of soybean (Glycine max) plants with AgNP-citrate has resulted in increased content of malondialdehyde (MDA), the end product of lipid peroxidation, thus indicating oxidative damage to membrane lipids [139]. Furthermore, elevated ROS production was reported in tobacco seedlings exposed to citrate-coated AgNPs [61], although the application of the same AgNPs to adult tobacco plants failed to induce oxidative stress [47]. This result suggests that plant age and developmental stage also might interfere with AgNP-induced phytotoxicity. In the study by Cvjetko et al. [65], the effects of electrostatically (citrate and CTAB) and sterically (PVP) stabilized AgNPs on roots of $A$. cepa were investigated. The results revealed that PVPcoated AgNPs had the least toxic effects on cell proteins, membranes, and DNA molecule in comparison to citrate- and particularly CTAB-coated ones. Moreover, Biba et al. [50], reported that CTAB-coated AgNPs had higher toxic effect on tobacco seedlings compared to AgNP-PVP. The stronger effect of electrostatically coated AgNPs on the formation of ROS may be related to their relative instability as discussed earlier. When S. polyrhiza was exposed to $6 \mathrm{~nm}$ AgNP-GA and $20 \mathrm{~nm}$ AgNP-PVP, only after the treatment with GA-coated AgNPs an increased MDA content was recorded. This finding was ascribed to AgNP-GA's smaller size and thus facilitated uptake compared to PVP-coated ones [100]. However, 
in pollen of kiwifruit (Actinidia deliciosa), Speranza et al. [142] have demonstrated that ROS and extracellular $\mathrm{H}_{2} \mathrm{O}_{2}$ production increased after treatment with PVP-coated AgNPs. Authors suggested that pollen as a reproductive plant organ may behave differently toward AgNP-induced stress than vegetative ones [142].

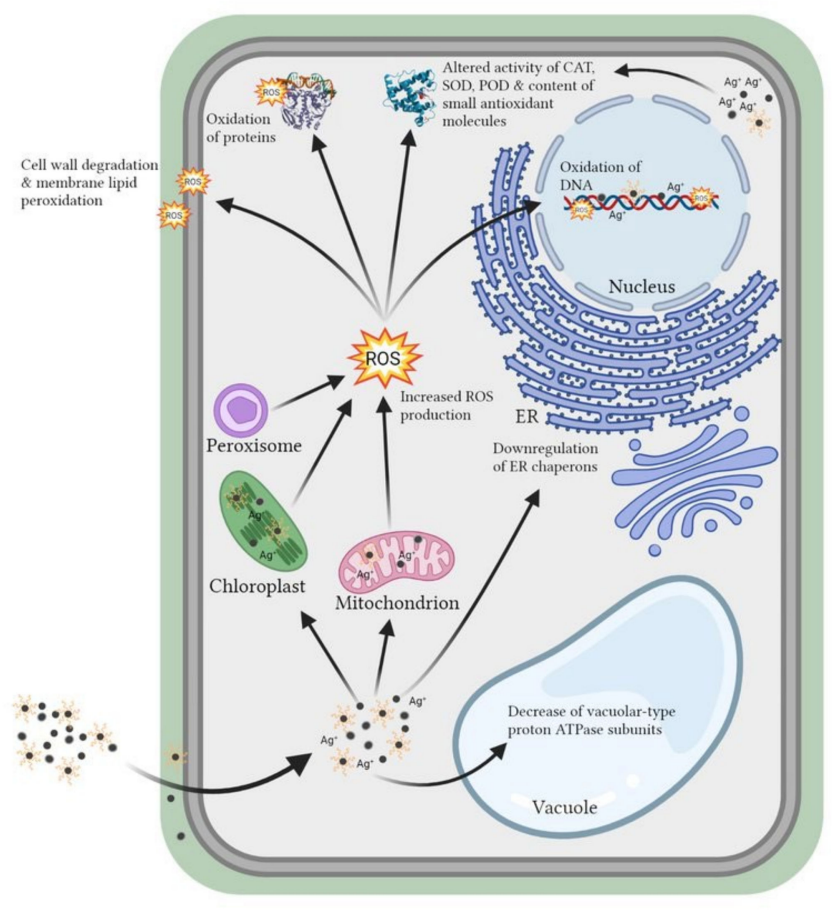

Figure 3. Effect of differently coated AgNPs on plant and algal cells by direct interaction or through ROS formation. ROS—reactive oxygen species, ER — endoplasmic reticulum, CAT—catalase, SODsuperoxide dismutase, POD—peroxidase. Adapted from "Structural Overview of a Plant Cell" by BioRender.com (2021). Retrieved from https:/ / app.biorender.com/biorender-templates. Accessed on 17 December 2021.

The balance between overproduction and scavenging of different ROS species in algae and plant cells upon exposure to AgNPs is regulated by antioxidant machinery [117]. Galazzi et al. [139] have demonstrated an increase in superoxide dismutase (SOD) and catalase (CAT) activity in soybean plants upon treatment with citrate-coated AgNPs. It was argued that the activity of both enzymes led to decomposition of $\mathrm{H}_{2} \mathrm{O}_{2}$ to $\mathrm{H}_{2} \mathrm{O}$ and $\mathrm{O}_{2}$, thus lowering the $\mathrm{H}_{2} \mathrm{O}_{2}$ content in plant cells. The increase in SOD and peroxidase (POD) activities was recorded in S. polyrhiza cells upon exposure to GA- and PVP-coated AgNPs, while CAT activity was significantly elevated only after the treatments with AgNP-GA [100]. Similar findings were reported when castor bean seedlings were exposed to PVP-coated AgNPs, which significantly elevated SOD and POD activity at all applied AgNP concentrations, while CAT activity increased only after the treatment with higher ones [117]. Similarly, an increase in POD activity was reported after the treatment of L. minor with citrate- and PVP-coated AgNPs, although AgNP-citrate was found to be more toxic. Interestingly, in the same study, CAT activity remained unchanged in all treatments regardless of the coating properties [120]. Cvjetko et al. [47] have revealed that the activity of antioxidant enzymes showed tissue specific responses. Namely, citrate-coated AgNPs induced CAT activity in roots of tobacco plants exposed to even lower AgNP concentrations, while in leaves, CAT and POD activities increased only after treatments with the highest one. The changes in activities of antioxidant enzymes in response to AgNPs were also reported in algae. Significant increase in SOD activity was found in C. reinhardtii cells after exposure to uncoated AgNPs, although POD activity was decreased [31]. Lekamge et al. [25] demonstrated that 
exposure of R. subcapitata to AgNPs stabilized with L-tyrosine and epigallocatechin gallate led to increased CAT activation, while curcumin-coated AgNPs increased CAT activity only after the highest applied concentration. In the study of Qian et al. [21], increased CAT as well as POD activity were also recorded after exposure of $C$. vulgaris to citrate-coated AgNPs, although no significant changes in ROS content were found. This result indicates that C. vulgaris efficiently alleviated AgNP-induced ROS overproduction by activation of antioxidant machinery. Glutathione-S-transferase (GST), which can metabolize and inactivate different secondary metabolites such as lipid hydroperoxides, was also found to play a role in defense against ROS toxicity mediated by nanoparticles [143]. Increased GST activity was measured upon exposure of common barley (Hordeum vulgare) to uncoated AgNPs [144] as well as in L. minor [120] and R. subcapitata [25] treated with PVP- and curcumin-coated AgNPs, respectively.

Besides enzymatic mechanism, plants and algae counteract oxidative stress by using small nonenzymatic antioxidant molecules such as proline, glutathione (GSH), and carotenoids in the process of ROS detoxification [100,145-147]. GSH acts as a scavenger of ROS [148] and, as a substrate in the synthesis of phytochelatins, can be indirectly involved in heavy metal detoxification $[100,149]$. Concentration-dependent increase of GSH content upon exposure to both GA- and PVP-coated AgNPs was reported in duckweed S. polyrhiza, where it efficiently alleviated oxidative stress, probably by chelating $\mathrm{Ag}^{+}$ions released from AgNPs [100]. Elevated carotenoid content was reported in O. sativa exposed to uncoated AgNPs [55], as well as in C. vulgaris [22] and tobacco [51,60], after exposure to AgNP-citrate. Carotenoids have an important role in preventing free radical reactions, and an increase in their concentration is one of the cell mechanisms to reduce the ROS toxicity [150]. However, it was also found that PVP- and citrate-coated AgNPs can induce a significant decrease of carotenoid content while simultaneously increasing proline amount in wheat [151] and O. sativa [141]. Decrease in carotenoid content may be a result of AgNP-induced toxic effects, which, in turn, damage carotenoid biosynthesis pathways [22,152]. On the other hand, an increase in proline content is considered as a systematic response to metal toxicity since proline is an important osmolyte. It acts as a metal chelator and thus may detoxify AgNP-induced ROS overproduction [153-155].

It is known that AgNPs can induce DNA damage either by direct AgNP interaction with DNA molecules or through AgNP-induced ROS formation [128,156,157]. Nevertheless, multiple studies have demonstrated that uncoated or differently coated AgNPs have induced oxidative damage while inducing aneugenic or clastogenic effects. Regarding the clastogenic effects, it was reported that uncoated as well as citrate- and PVP-coated AgNPs induced DNA breaks in V. faba [82], tobacco [61,156], and A. cepa [65,135,158,159], respectively, while uncoated and PVP-coated ones further induced chromosomal aberrations and increased levels of micronucleus [82,159]. Moreover, concerning the aneugenic outcomes, exposure to uncoated AgNPs as well as to those coated with either citrate or PVP has led to a significant decrease in mitotic index in $V$. faba [82] and $A$. cepa $[65,158,159]$. However, no genotoxic effects were found upon exposure of $A$. cepa roots to AgNPs coated with PVP [160] or chitosan [161], as well as after exposing tobacco plants to AgNP-citrate [47]. Reported lack of genotoxicity could be a result of longer exposure time during which DNA damage could be repaired. Up to this day, to the best of our knowledge, no studies have evaluated DNA damage to algal species after treatment with silver nanoparticles.

Although oxidative stress plays an important role in the toxicity mechanism of AgNPs, it is still not clear whether production of ROS is a directly or indirectly affected through release of $\mathrm{Ag}^{+}$ions, as, in most of the studies evaluated in this review, detailed analysis of AgNPs stability is missing. Differentially coated AgNPs show different extents of ROS production as well as altered activity of antioxidative enzymes. The overall results suggest that coating-stabilized AgNPs influence plant and green algae response to stressful conditions in time- and concentration-dependent manner, although plant developmental stage can also interfere with the extent of AgNP-induced oxidative stress. 


\section{Impact on Photosynthesis}

Most research to date shows that photosynthesis, the most important biochemical process on Earth for providing energy and oxygen, is particularly sensitive to AgNPs (Figure 4). Several studies have reported a decrease in chlorophyll content upon exposure to uncoated AgNPs in freshwater algae C. vulgaris [18,34], P. oedogonia and Chara vulgaris [27], and C. reinhardtii [31], as well as vascular plants, e.g., rice [141,162] and A. thaliana [163]. A decline in chlorophyll content was also observed upon exposure to AgNPs stabilized with different surface coatings, e.g., in freshwater algae Scenedesmus after exposure to AgNP-PVA [26], C. vulgaris treated with AgNP-glucose [35] and AgNP-citrate [22], and in A. thaliana exposed to AgNP-citrate [90]. AgNP-induced reduction of carotenoid content has also been reported upon treatment of $A$. thaliana with AgNP-citrate $[90,92]$ and in $O$. sativa exposed to uncoated AgNPs [141]. The observed decrease in content of chlorophyll $a$, a major photosynthetic pigment, was also found to be accompanied with the inhibition of photosynthetic performance after exposure of fresh water green algae to different AgNPs. Uncoated AgNPs decreased chlorophyll content as well as maximum quantum yield for primary photochemistry and electron transport activity in C. vulgaris [32]. Moreover, they also induced structural deterioration of photosystem II (PSII) reaction center, the alteration of the oxygen-evolving complex, and the inhibition of electron transport in $C$. reinhardtii [17]. Inhibited photosynthetic yield was also reported in $R$. subcapitata exposed to AgNP-PVP [23] and in E. gracilis upon exposure to AgNP-citrate [39,40].

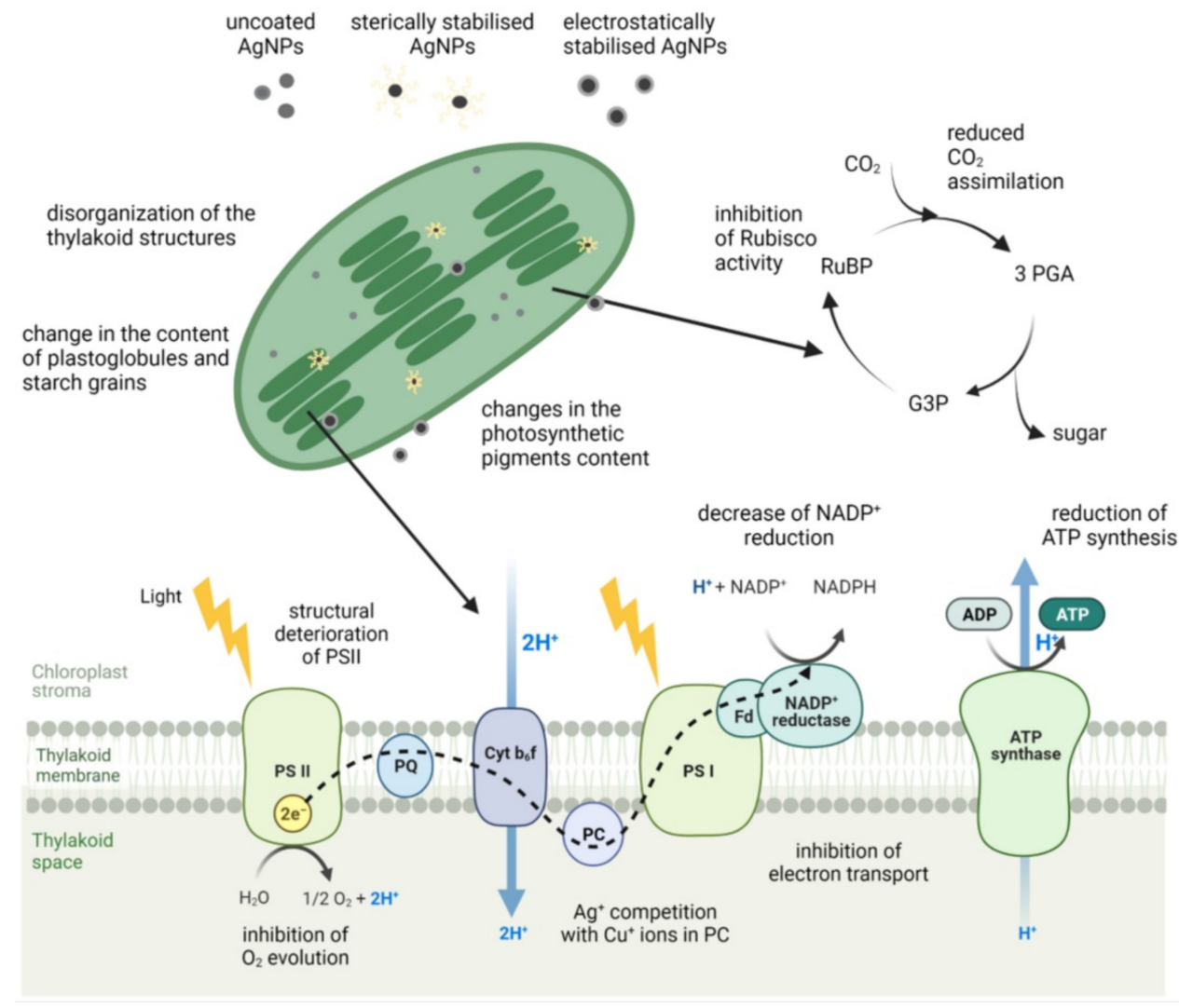

Figure 4. Structural and functional changes of the photosynthetic apparatus in plants and freshwater algae upon exposure to AgNPs with different surface coatings. RuBP—ribulose 1,5-bisphosphate, 3-PGA-3-phosphoglyceric acid, G3P-glyceraldehyde 3-phosphate, PS-photosystem, PQplastoquinone, Cyt b6f—cytochrome b6f, PC—plastocyanin, Fd-ferredoxins. Figure was adapted from "Light Dependent Reactions of Photosynthesis" by BioRender.com (2021). Retrieved from https:/ / app.biorender.com/biorender-templates. Accessed on 24 November 2021. 
In vascular plants, uncoated AgNPs significantly declined the content of photosynthetic pigments and photosynthetic efficiency in Arabidopsis [163]. Moreover, exposure to AgNP-GA [58] and AgNP-PVP [46] reduced chlorophyll content and inhibited maximum quantum yield and electron transport rate in duckweed $S$. polyrhiza. In another duckweed species, W. globose, the decrease in chlorophyll content and photosynthetic ability was reported after AgNP-ATP treatment and, less pronounced, after exposure to AgNP-citrate [164]. The inhibition of PSII photochemical reactions has been also found in Arabidopsis exposed to AgNP-citrate [90,92], Lemna gibba plants treated with uncoated AgNPs [165], and $V$. faba exposed to AgNP-PVP [49]. These results indisputably indicate that AgNPs induce inhibition of PSII activity, which results in the inhibition of electron transport activity and, consequently, increases production of ROS [34,46]. Moreover, a number of studies reported a correlation between AgNP-induced ROS generation and negative effects on photosynthetic parameters in both algae [18,31,34] and plants $[46,54,92,141,166]$.

Although the exact mechanism of AgNP phytotoxicity is still not fully understood, AgNPs in the cell may dissociate to the toxic $\mathrm{Ag}^{+}$ions [1]. They can competitively replace $\mathrm{Cu}^{+}$ions in plastocyanin, an electron carrier in the photosynthetic electron-transfer chain, resulting in the disturbance of the photosynthetic electron transport and ROS generation $[167,168]$. Furthermore, $\mathrm{Ag}^{+}$can interact with the thiol group of enzymes of chlorophyll biosynthesis, thus interfering with this process [168]. Another possible explanation for impaired photosynthesis could be diminished transpiration rate and stomatal conductance, resulting in lower rate of gas exchange and reduced $\mathrm{CO}_{2}$ assimilation, as found in L. sativa [169] and $V$. faba [49] after exposure to AgNP-PVP and in rice after treatment with uncoated AgNPs [162]. Similarly, after exposure of tomato plants to AgNP-PEG, a significant decrease in chlorophyll content and severely disrupted $\mathrm{CO}_{2}$ assimilation efficiency were found [54]. Slowing $\mathrm{CO}_{2}$ assimilation rate could be linked to AgNP-imposed inhibition of Rubisco activity, as this enzyme showed to be very sensitive to $\mathrm{Ag}^{+}$ions [46]. Consequently, the demand for NADPH and ATP is limited, decreasing energy consumption that, when in excess, induces ROS generation and damage to chloroplasts [46]. Microscopic analyses of chloroplasts confirmed that exposure to various AgNPs disturbs their structure. In a study by Cvjetko et al. [47], chloroplasts in leaves of tobacco plants exposed to AgNP-citrate were found to be smaller than in control plants, although the thylakoid system remained well developed. Yet in another study, citrate-, PVP-, and CTAB-coated AgNPs induced disturbance in the chloroplast ultrastructure of tobacco leaves [51]. The observed difference in the effect of AgNP-citrate may be due to the higher stability of electrostatically stabilized AgNP-citrate in distilled water used as an exposure medium in the former study [47] compared to MS medium applied for plant treatment in the later study [51]. Chloroplasts of $A$. thaliana seedlings treated with uncoated AgNPs appeared to be slightly flatter and the grana lamellae, thinner, and thylakoid membranes became more spread out [163]. Furthermore, chloroplasts with accumulated starch grains as well as with fewer intergranal thylakoids were observed in duckweeds after exposure to sterically stabilized AgNP-GA and AgNP-PVP [100] as well as AgNP-PVA [57].

However, stimulatory effects of AgNPs on photosynthesis have also been found. An increase in chlorophyll content was observed in fenugreek Trigonella foenumgraecum after AgNP-citrate exposure [170] as well as in vanilla and sugarcane treated with sterically stabilized AgNP-PVP [171,172]. In seedlings of brown mustard (Brassica juncea), upon exposure to AgNP-citrate, increased chlorophyll content was recorded, while photosynthetic quantum efficiency improved, indicating that higher number of reaction centers were in an "open state" to carry out light reaction [173]. Interestingly, in tobacco seedlings, upon exposure to AgNP-citrate, enhanced chlorophyll content was measured, although photosynthetic efficiency remained unaltered [60]. Furthermore, an increase in the carotenoids content after the treatment with uncoated AgNPs was observed in rice [55] and in tobacco exposed to AgNP-citrate [51,60]. A foliar application of uncoated AgNPs stimulated chlorophyll synthesis in the leaves of T. aestivum, while in lettuce showed no effects [174]. In Stevia rebaudiana treated with AgNP-PVP, the increase in the content of photosynthetic pigments 
was explained as a consequence of observed increase in $\mathrm{N}, \mathrm{Mg}$, and Fe concentrations, since these elements are associated with chlorophyll biosynthesis [175]. Moreover, increase in leaf chlorophyll content correlated with enhanced N and P uptake in Phaseolus vulgaris [54] and with increased levels of K, Ca, and S in Lilium [176], both treated with uncoated AgNPs. Thus, it can be assumed that positive effects of AgNPs on photosynthetic processes observed in some cases can be attributed to enhanced mineral uptake.

Inconsistent plant responses to AgNPs may be due to the difference in intrinsic properties of differently coated AgNPs used in toxicity studies. However, only a few studies compared the effect of AgNPs with different surface coatings on photosynthetic parameters in the same plant/algal species and test conditions. In algae C. vulgaris, inhibitory effects of differently coated AgNPs were compared by measuring chlorophyll content, and the results showed that PEG-coated AgNPs had the least effect, whereas AgNP-PVP and AgNP-citrate had similar inhibitory effect [33]. Navarro et al. [20] investigated the effect of nine differently coated AgNPs (chitosan, lactate, PVP, PEG, gelatin, sodium dodecyl benzene sulfonate, citrate, dexpanthenol, and carbonate) on photosynthetic yield of $C$. reinhardtii. All differently coated AgNPs proved to be toxic, decreasing the photosynthetic yield of algae in a dose-dependent manner. Interestingly, the addition of cysteine, a strong $\mathrm{Ag}^{+}$ligand, completely prevented effects on photosynthetic yield, confirming that $\mathrm{Ag}^{+}$ ions play a significant role in the AgNP effect on photosynthesis in algae $[15,20,177]$. In C. vulgaris exposed to citrate- and PVP-coated AgNPs, the concentrations of photosynthetic pigments displayed an increment at lower AgNP concentrations but then significantly decreased at higher concentrations [22]. Different responses to different AgNP doses may be the effect of hormesis, i.e., low doses have a stimulatory effect, while high doses have inhibitory impact [176]. In a study of Liang et al. [121], after exposure of P. patens to uncoated AgNPs, content of chlorophylls decreased significantly in protonemata, while the exposure to coated AgNPs resulted with either no significant difference (AgNP-citrate) or increase in chlorophyll content (AgNP-PVP). These results lead to conclusion that surface coatings alleviated the damaging effect of uncoated AgNPs, probably influencing their bioavailability in the exposure medium. The effect of AgNPs with different surface coatings (citrate, PVP, and PEG) was also conducted in L. sativa, and the results showed that the transpiration rate and stomatal conductance only diminished in plants exposed to AgNP-PVP [169]. Interestingly, an enhanced photochemical efficiency and increase in all photosynthetic pigments content was observed upon treatments with PVP- and PEGcoated AgNPs, while AgNP-citrate did not cause any significant effect [169]. In the study of Peharec Štefanić et al. [51] on tobacco, the effects of three differently coated AgNPs (citrate, PVP, and CTAB) were cross-compared, and the obtained results showed that the extent of photosynthetic damage depended on the coating, with AgNP-citrate having the least effect. On the other hand, AgNP-PVP and AgNP-CTAB induced more significant decline in the content of chlorophylls and xanthophylls as well as had a strong inhibitory effect on the photosynthetic performance. Authors suggested that milder effects of AgNP-citrate could derive from their fast agglomeration in the exposure medium and, consequently, lower bioavailability. On the other hand, more severe impact of other two AgNP types was probably due to the positive surface charge of AgNP-CTAB and higher stability of AgNP-PVP, resulting in their longer availability for uptake [51]. In the same study, an increase in the nonphotochemical quenching (NPQ) and xanthophyll content related to the inhibition of PSII photochemical reactions was observed in plants treated with AgNPcitrate. Increased energy dissipation through NPQ and downregulation of electron flow can protect PSII against overexcitation and damage [177]. Similar findings have also been found in Arabidopsis exposed to AgNP-citrate [91,93] as well as in L. gibba plants treated with uncoated AgNPs [164] and V. faba exposed to AgNP-PVP [50].

In conclusion, exposure of plants and freshwater algae to AgNPs with different surface coatings can cause both structural changes of the photosynthetic apparatus and functional ones that manifest as a decrease in the content of photosynthetic pigments, as well as an inhibition of photochemical reactions and $\mathrm{CO}_{2}$ assimilation. The divergence of the AgNP- 
induced effects on photosynthesis can be partly attributed to differences in physicochemical characteristics of AgNPs and their bioavailability imposed by different surface coatings. However, the effect of other factors such as plant species, developmental phase, type, and time of exposure should be also considered.

\section{Changes in Gene and Protein Expression}

The application of AgNPs modulates morphophysiological, biochemical, and molecular status of plants and freshwater green algae. In spite of the attention that nanomaterial phytotoxicity attracted in recent years, only limited investigations have been conducted on the molecular level effects of AgNPs in plants, while for studies on green algae, even less information in the literature can be found. To examine the molecular bases of AgNP phytotoxicity, gene and protein expression analyses have been performed in model as well as in different crop plants and only a few species of freshwater green algae.

One of the main mechanisms through which AgNPs mediate their effects involves oxidative stress. Most studies revealed altered expression of genes and proteins encoding for plant cell antioxidant machinery. Nair and Chung [141] observed that the expression level of SOD genes (FSD, MSD1 and CSD1) was induced in shoots and roots of rice seedlings upon exposure to different concentrations of citrate-coated AgNPs. Upregulation of SOD genes, which encode for enzymes that are considered the first line of cellular defense against oxidative stress, was also shown in A. thaliana leaves [44] and seedlings [178] upon exposure to AgNP-PVP. Similar findings were also reported in the roots of wheat plants treated with sulfidized AgNPs [179]. Moreover, the studies have shown an upregulation of genes for CAT, also involved in ROS scavenging, in several plant species (rice and tomato seedlings, Arabidopsis leaves, and wheat roots) treated with differently coated AgNPs (citrate, PVP, and sulfide) $[44,141,179,180]$. Furthermore, transcriptional upregulation of ascorbate peroxidase $(A P X)$ genes was observed in rice shoots upon exposure to citratecoated AgNPs [141]. This finding, in correlation with higher $\mathrm{H}_{2} \mathrm{O}_{2}$ formation, suggests protections of cells from excess accumulation of $\mathrm{H}_{2} \mathrm{O}_{2}$ through the ascorbate-glutathione cycle, where APX reduces the $\mathrm{H}_{2} \mathrm{O}_{2}$ to $\mathrm{H}_{2} \mathrm{O}$ [141]. AgNP-PVP treatment of $A$. thaliana seedlings [178] and roots [118] also caused upregulation of $P O D$ genes, which encode another group of antioxidant enzymes. Proteomic analyses confirmed the importance of defense against oxidative stress in plants exposed to AgNPs. Induced protein expression of enzymatic antioxidants including SOD, CAT, and POD was reported in rocket [116] and tomato seedlings [180] upon exposure to AgNP-PVP. Interestingly, in the studies of the impact of the same concentration of AgNP-citrate, upregulation of antioxidant enzymes was recorded in tobacco seedlings [61], but in the leaves and roots of adult tobacco plants, the same proteins were downregulated [89]. These findings indicate that, regardless of the applied AgNP coating and concentration, plant age and developmental stage might have a significant role in response to AgNP-imposed stress. In the studies of freshwater green algae, upregulation of gene and protein expression of antioxidant enzymes was recorded in C. vulgaris upon exposure to AgNP-citrate [21], while downregulation of SOD expression was reported in C. reinhardtii treated with PEG-coated AgNP [28].

Besides antioxidant enzymes, plant cells can protect themselves against oxidative stress by nonenzymatic molecules such as sulfur-containing compounds, GSH, phenolics, and carotenoids [181,182]. Nair and Chung [80] observed upregulation in the expression level of genes involved in the sulfur assimilation pathway (ATP sulfurylase, ATPS), phytochelatin synthesis (phytochelatin synthase, PCS), and GSH biosynthesis after exposure of $A$. thaliana to citrate-coated AgNPs. Upregulation was also found for GST and glutathione reductase $(G R)$ genes. Authors concluded that the differential modulation of genes involved in sulfur assimilation and GSH biosynthesis, GR, GST, and PCS, shows the biological role of these pathways in dealing with AgNP-mediated stress response. Moreover, proteomic analyses of rocket roots demonstrated upregulation of proteins involved in metabolism of sulfur-containing amino acids, methionine, and cysteine [45]. Namely, AgNP-PVP exposure caused the accumulation of a vitamin-B12-independent methionine synthase 
isozyme involved in the biosynthesis of the methionine and cysteine synthase, a key enzyme in cysteine biosynthesis [45]. Cysteine is a direct coupling step between sulfur and its incorporation into GSH, important in plant stress tolerance to ROS. Upregulation in the expression of key genes of flavonoid and anthocyanin biosynthesis pathway was found in A. thaliana plants exposed to AgNP-citrate [183]. Flavonoids are the most abundant compound of phenolics, secondary metabolites that act as free-radical terminators, and anthocyanin commonly serves as a nonenzymatic antioxidant to scavenge free radicals and chelate metals under stress conditions.

Treatments with various AgNPs also had an impact on transcriptional status of genes associated with the plant response to pathogens. In the study of Kaveh et al. [178], exposure of $A$. thaliana seedlings to AgNP-PVP led to downregulation of genes involved in systemic acquired resistance (SAR). SAR is a signaling mechanism that is triggered upon infection by certain pathogens or by mechanical damage and results in thickening of the cell wall and other physiological responses that enhance general plant defenses. In A. thaliana exposed to citrate-coated AgNPs, Garcia-Sanchez et al. [183] showed downregulation of genes that are key components of the pathogen-detection pathways that activate SAR and salicylic acid signaling. However, salt stress- and wounding-related genes as well as genes involved in the thalianol biosynthetic pathway, a part of the plant defense mechanism, were found to be upregulated in A. thaliana after exposure to AgNP-PVP [178]. Following exposure to $\mathrm{Ag}_{2} \mathrm{~S}-\mathrm{AgNPs}$, two miraculin-like protein genes were upregulated in cucumber and wheat leaves [184], while in wheat roots, an enhanced regulation of pathogen-inducible ethylene-responsive element-binding protein was recorded [179]. Treatment with AgNPPVP upregulated expression of chitinases and pathogenesis-related proteins in wheat seedlings [45]. Similar findings were also reported for tobacco seedlings exposed to AgNPcitrate [61]; however, when adult tobacco plants were exposed to the same treatments, a significant downregulation of the same proteins was recorded [89].

Proteomic studies performed on different plant species showed that AgNPs altered abundance of proteins involved in primary metabolism, suggesting that metabolic adaptation of plants plays an important role in mitigating unfavorable changes in the environment $[45,61]$. Photosynthesis was found to be seriously affected on both proteomic and genomic level upon exposure of plants to either citrate-coated [61,89,92] or PVP-coated AgNPs $[44,45]$. Similar studies, performed on freshwater green algae, also revealed the strong impact of AgNP-treatments on photosynthetic proteins. Upon exposure of C. reinhardtii to PEG-coated AgNP, the majority of the proteins with enhanced expression were those involved in photosynthesis and Calvin cycle [28]. In the study of Liu et al. [185], in which Nostoc sp. was exposed to uncoated AgNPs, differentially expressed proteins related to photosynthesis including phycobilisome, photosynthetic membrane, PSII, and PSI reaction center proteins were found to be affected, with PSII proteins being up-, and PSI proteins downregulated. Upon exposure of C. vulgaris to AgNP-citrate, an enhanced expression of Rubisco large chain was recorded, while alpha and beta subunits of ATP synthase were found to be downregulated [21]. All these findings on both plants and green algae suggest that photosynthesis is a cell process particularly affected by AgNP-treatments, regardless of the applied stabilizing agent.

Enhanced expression of proteins involved in glycolysis, an important metabolic pathway responsible for conversion of glucose to pyruvate, was recorded after exposure of tobacco seedlings to AgNP-treatment [61]. In rocket, treatment with PVP-coated AgNPs induced the accumulation of the glyoxalase I enzyme involved in detoxification of methylglyoxal, which is a cytotoxic byproduct of glycolysis that accumulates in cells in response to environmental stresses [116]. Furthermore, AgNPs changed the expression of proteins related to protein folding. In particular, Vannini et al. [116] found the downregulation of two chaperons involved in endoplasmic reticulum (ER)-associated degradation and the decrease of two vacuolar-type proton ATPase subunits in rocket seedlings. These findings indicate that ER and vacuole are targets of the AgNP-PVP action. Similar results were reported in wheat roots, where a strong influence of AgNP-PVP on the ER is suggested 
due to the decreased levels of three ER-resident proteins [45]. Furthermore, treatment of tobacco seedlings with citrate coated AgNPs also showed changed expression of proteins involved in protein folding [61].

In addition to aforementioned effects, AgNPs can also have an effect associated with hormonal signaling. Most of the auxin-receptor related genes were downregulated in A. thaliana exposed to AgNP-PVP [186], while $\mathrm{Ag}_{2} \mathrm{~S}-\mathrm{NPs}$ upregulated genes involved in ethylene signaling pathway in wheat and cucumber [184]. Both hormones are important for plant growth regulation. Moreover, in the study of Kaveh et al. [178], A. thaliana exposure to PVP-coated AgNPs was associated with the downregulation of auxin-regulated gene involved in organ size and ethylene signaling pathway.

In the studies performed on green algae, several distinctive effects in gene and protein expression were recorded. Leclerc and Wilkinson [30] have reported an increase in transcript levels of genes encoding known or predicted components of the cell wall and the flagella after treatment of $C$. reinhardtii with polyacrylate-coated AgNPs. This increase in transcript levels can be explained by the attempt of algae cells to recover AgNP-induced damage to the external structures of the cells. Upon exposure of C. reinhardtii cells to PVPcoated AgNP, a significant increase was found for cytochrome c6 (CYC6) and ferredoxin-5 (FDX5) genes, which was considered to be an indicator of the copper deficiency [122]. Furthermore, after exposure of the same algae to the polyacrylate-coated AgNPs, an increased expression level of the copper transport protein 2 (CTR2) was reported [30]. This finding can be explained by $\mathrm{Ag}^{+}$internalization into cell through $\mathrm{Cu}(\mathrm{I})$ transporter. Particularly interesting is the study of Zhang et al. [29], who compared effects of two differently coated AgNPs, negatively charged AgNP-citrate and positively charged AgNP-PEI, on protein expression in C. vulgaris, and revealed that citrate-coated AgNPs induced downregulation of mitochondrial function-related proteins, resulting in the disruption of metabolic pathways related to energy metabolism, oxidative phosphorylation, and amino acid synthesis. On the other hand, positively charged AgNP-PEI primarily targeted ribosome function-related proteins and interrupted pathways of protein synthesis and DNA genetic information transmission. These findings suggest that coating applied for AgNP stabilization might induce different response in protein expression within the algae cell.

In conclusion, studies have shown that differently coated AgNPs have impact on gene and protein expression in various plant and algae species. Information obtained from these studies increase our understanding of the mechanisms involved in plant and green algae responses to AgNPs, which is relevant for environmental assessments. However, it is difficult to draw unambiguous conclusions since these studies have been investigated in different species, applied different concentrations of AgNPs with different coatings, and employed different exposure times. Therefore, in order to investigate the role of stabilizing coatings in AgNP-induced phytotoxicity on molecular level and to be able to compare different coatings, it would be useful to conduct a research that implemented differently coated AgNPs in the same experimental setup.

\section{Conclusions}

AgNP behavior in plant and algal exposure systems is dependent on surface coatings. On one hand, they stabilize nanoparticles, but on the other hand, are responsible for their physiochemical modifications, such as changes in aggregation and agglomeration, oxidation states, and dissolution rate of $\mathrm{Ag}^{+}$ions. Surface coating-determined AgNP properties play an important role in AgNP uptake and modulate their effects on germination and development in plants. In algae, EPS plays an important role in AgNP bioaccumulation, which is why effects of differently coated AgNPs on EPS should be further investigated. Oxidative stress is proved to be the one of the major mechanisms of the AgNP-induced phytotoxicity in both plants and algae, although application of certain surface coatings seems to alleviate AgNP-induced ROS formation. The process of photosynthesis, in all its complexity, has been particularly affected by AgNPs, although algae, being unicellular organisms, seem to be more susceptible compared to plants. At the molecular level, gene 
and protein expression analyses confirmed AgNP-generated induction of oxidative stress and photosynthesis as the most sensitive target of AgNP toxic action, regardless of which coating is applied. However, in order to investigate the role of stabilizing coatings in AgNPinduced phytotoxicity on molecular level and to be able to compare different coatings, it would be useful to conduct a more studies which will implement differently coated AgNPs in the same experimental setup.

Author Contributions: Conceptualization, B.B.; writing-original draft preparation, R.B., K.K., B.K. and D.M.; writing—review and editing, B.B., P.C., M.T., D.P. and P.P.Š.; visualization, R.B., K.K., B.K., B.B. and M.T. All authors have read and agreed to the published version of the manuscript.

Funding: This research has received funding from the Croatian Science Foundation [grant numbers IP-2014-09-6488 and IP-2018-01-5351] and the European Union Seventh Framework Programme under Grant Agreement 312483-ESTEEM2 (Integrated Infrastructure Initiative-I3).

Institutional Review Board Statement: Not applicable.

Informed Consent Statement: Not applicable.

Data Availability Statement: The data used to support the findings of this study are included within the article.

Conflicts of Interest: The authors declare no conflict of interest.

\begin{abstract}
Abbreviations
AgNP—silver nanoparticle, APX — ascorbate peroxidase, ATPS—ATP sulfurylase, BBM—Bold's basal medium, BG-11 medium - medium for blue green algae, CAT—catalase, CSD—CuZnSOD, CTABcetyltrimethylammonium bromide, CTR2 - copper transport protein 2, CYC6-cytochrome c6, Cyt b6f-cytochrome b6f, DDAB — didecyldimethylammonium bromide, DLS—dynamic light scattering, EDTA — ethylenediaminetetraacetic acid, EPS—extracellular polymeric substances, ER —endoplasmic reticulum, Fd-ferredoxin, FDX5—ferredoxin-5, FSD—FeSOD, G3P-glyceraldehyde 3-phosphate, GA — gum Arabic, GR — glutathione reductase, GSH—glutathione, GST—glutathione-S-transferase, HSM-high salt medium, MOPS-3-morpholinopropanesulfonic acid, MS-Murashige and Skoog, MSD—MnSOD, NDB—Na-dodecylbenzenesulfonate, NPQ—nonphotochemical quenching, PC plastocyanin, PCS - phytochelatin synthase, PEG-polyethylene glycol, PEI-polyethyleneimine, 3-PGA-3-phosphoglyceric acid, POD—peroxidase, PQ-plastoquinone, PS-photosystem, PVApolyvinyl alcohol, PVP-polyvinylpyrrolidone, ROS—reactive oxygen species, RuBP—ribulose 1,5-bisphosphate, SAR — systemic acquired resistance, SDS—sodium dodecyl sulphate, SE—sludge extract, SOD—superoxide dismutase, TAP—Tris-acetate-phosphate, TEM—transmission electron microscope, USEPA-U. S. Environmental Protection Agency.
\end{abstract}

\title{
References
}

1. Tkalec, M.; Peharec Štefanić, P.; Balen, B. Phytotoxicity of silver nanoparticles and defence mechanisms. Compr. Anal. Chem. 2019, 84, 145-198. [CrossRef]

2. Yin, I.X.; Zhang, J.; Zhao, I.S.; Mei, M.L.; Li, Q.; Chu, C.H. The antibacterial mechanism of silver nanoparticles and its application in dentistry. Int. J. Nanomed. 2020, 15, 2555-2562. [CrossRef]

3. Ray, Paresh Chandra; Hongtao, Y.; Fu, P.P. Toxicity and environmental risks of nanomaterials: Challenges and future needs. Env. Sci Heal. C Env. Carcinog. Ecotoxicol. Rev. 2009, 27, 1-35. [CrossRef] [PubMed]

4. Smita, S.; Gupta, S.K.; Bartonova, A.; Dusinska, M.; Gutleb, A.C.; Rahman, Q. Nanoparticles in the environment: Assessment using the causal diagram approach. Environ. Heal. A Glob. Access Sci. Source 2012, 11, S13. [CrossRef] [PubMed]

5. Bae, S.; Hwang, Y.S.; Lee, Y.-J.; Lee, S.-K. Effects of water chemistry on aggregation and soil adsorption of silver nanoparticles. Environ. Health Toxicol. 2013, 28, e2013006. [CrossRef]

6. Behra, R.; Sigg, L.; Clift, M.J.D.; Herzog, F.; Minghetti, M.; Johnston, B.; Petri-Fink, A.; Rothen-Rutishauser, B. Bioavailability of silver nanoparticles and ions: From a chemical and biochemical perspective. J. R. Soc. Interface 2013, 10. [CrossRef] [PubMed]

7. De Leersnyder, I.; De Gelder, L.; Van Driessche, I.; Vermeir, P. Revealing the importance of aging, environment, size and stabilization mechanisms on the stability of metal nanoparticles: A case study for silver nanoparticles in a minimally defined and complex undefined bacterial growth medium. Nanomaterials 2019, 9. [CrossRef] 
8. Levard, C.; Reinsch, B.C.; Michel, F.M.; Oumahi, C.; Lowry, G.V.; Brown, G.E. Sulfidation processes of PVP-coated silver nanoparticles in aqueous solution: Impact on dissolution rate. Environ. Sci. Technol. 2011, 45, 5260-5266. [CrossRef] [PubMed]

9. Levard, C.; Hotze, E.M.; Lowry, G.V.; Brown, G.E. Environmental transformations of silver nanoparticles: Impact on stability and toxicity. Environ. Sci. Technol. 2012, 46, 6900-6914. [CrossRef]

10. Yin, L.; Cheng, Y.; Espinasse, B.; Colman, B.P.; Auffan, M.; Wiesner, M.; Rose, J.; Liu, J.; Bernhardt, E.S. More than the ions: The effects of silver nanoparticles on Lolium multiflorum. Environ. Sci. Technol. 2011, 45, 2360-2367. [CrossRef]

11. Sharma, V.K.; Siskova, K.M.; Zboril, R.; Gardea-Torresdey, J.L. Organic-coated silver nanoparticles in biological and environmental conditions: Fate, stability and toxicity. Adv. Colloid Interface Sci. 2014, 204, 15-34. [CrossRef]

12. Tolaymat, T.M.; El Badawy, A.M.; Genaidy, A.; Scheckel, K.G.; Luxton, T.P.; Suidan, M. An evidence-based environmental perspective of manufactured silver nanoparticle in syntheses and applications: A systematic review and critical appraisal of peer-reviewed scientific papers. Sci. Total Environ. 2010, 408, 999-1006. [CrossRef]

13. Biba, R.; Peharec Štefanić, P.; Cvjetko, P.; Tkalec, M.; Balen, B. Silver nanoparticles phytotoxicity mechanisms. In Nanobiotechnology for Plant Protection; Silver Nanomaterials for Agri-Food Applications; Kamel, A.A.-E., Ed.; Elsevier: Amsterdam, The Netherlands, 2021; pp. 317-356, ISBN 9780128235287.

14. Wang, S.; Lv, J.; Ma, J.; Zhang, S. Cellular internalization and intracellular biotransformation of silver nanoparticles in Chlamydomonas reinhardtii. Nanotoxicology 2016, 10, 1129-1135. [CrossRef]

15. Navarro, E.; Baun, A.; Behra, R.; Hartmann, N.B.; Filser, J.; Miao, A.J.; Quigg, A.; Santschi, P.H.; Sigg, L. Environmental behavior and ecotoxicity of engineered nanoparticles to algae, plants, and fungi. Ecotoxicology 2008, 17, 372-386. [CrossRef] [PubMed]

16. Piccapietra, F.; Allué, C.G.; Sigg, L.; Behra, R. Intracellular silver accumulation in Chlamydomonas reinhardtii upon exposure to carbonate coated silver nanoparticles and silver nitrate. Environ. Sci. Technol. 2012, 46, 7390-7397. [CrossRef]

17. Dewez, D.; Oukarroum, A. Silver nanoparticles toxicity effect on photosystem II photochemistry of the green alga Chlamydomonas reinhardtii treated in light and dark conditions. Toxicol. Environ. Chem. 2012, 94, 1536-1546. [CrossRef]

18. Oukarroum, A.; Bras, S.; Perreault, F.; Popovic, R. Inhibitory effects of silver nanoparticles in two green algae, Chlorella vulgaris and Dunaliella tertiolecta. Ecotoxicol. Environ. Saf. 2012, 78, 80-85. [CrossRef] [PubMed]

19. Matorin, D.N.; Todorenko, D.A.; Seifullina, N.K.; Zayadan, B.K.; Rubin, A.B. Effect of silver nanoparticles on the parameters of chlorophyll fluorescence and P700 reaction in the green alga Chlamydomonas reinhardtii. Microbiology 2013, 82, 809-814. [CrossRef]

20. Navarro, E.; Wagner, B.; Odzak, N.; Sigg, L.; Behra, R. Effects of differently coated silver nanoparticles on the photosynthesis of Chlamydomonas reinhardtii. Environ. Sci. Technol. 2015, 49, 8041-8047. [CrossRef]

21. Qian, H.; Zhu, K.; Lu, H.; Lavoie, M.; Chen, S.; Zhou, Z.; Deng, Z.; Chen, J.; Fu, Z. Contrasting silver nanoparticle toxicity and detoxification strategies in Microcystis aeruginosa and Chlorella vulgaris: New insights from proteomic and physiological analyses. Sci. Total Environ. 2016, 572, 1213-1221. [CrossRef]

22. Romero, N.; Visentini, F.F.; Márquez, V.E.; Santiago, L.G.; Castro, G.R.; Gagneten, A.M. Physiological and morphological responses of green microalgae Chlorella vulgaris to silver nanoparticles. Environ. Res. 2020, 189. [CrossRef]

23. Wang, Z.; Quik, J.T.K.; Song, L.; Van Den Brandhof, E.J.; Wouterse, M.; Peijnenburg, W.J.G.M. Humic substances alleviate the aquatic toxicity of polyvinylpyrrolidone-coated silver nanoparticles to organisms of different trophic levels. Environ. Toxicol. Chem. 2015, 34, 1239-1245. [CrossRef] [PubMed]

24. Kleiven, M.; Macken, A.; Oughton, D.H. Growth inhibition in Raphidocelis subcapita - evidence of nanospecific toxicity of silver nanoparticles. Chemosphere 2019, 221, 785-792. [CrossRef] [PubMed]

25. Lekamge, S.; Miranda, A.F.; Abraham, A.; Ball, A.S.; Shukla, R.; Nugegoda, D. The toxicity of coated silver nanoparticles to the alga Raphidocelis subcapitata. SN Appl. Sci. 2020, 2, 1-14. [CrossRef]

26. Pham, T.L. Effect of silver nanoparticles on tropical freshwater and marine microalgae. J. Chem. 2019, 2019. [CrossRef]

27. Dash, A.; Singh, A.P.; Chaudhary, B.R.; Singh, S.K.; Dash, D. Effect of silver nanoparticles on growth of eukaryotic green algae. Nano-Micro Lett. 2012, 4, 158-165. [CrossRef]

28. Lindgren, A.L. The effects of silver nitrate and silver nanoparticles on Chlamydomonas reinhardtii: A proteomic approach. Master's Thesis, University of Gothenburg, Gothenburg, Sweden, 2014.

29. Zhang, J.; Shen, L.; Xiang, Q.; Ling, J.; Zhou, C.; Hu, J.; Chen, L. Proteomics reveals surface electrical property-dependent toxic mechanisms of silver nanoparticles in Chlorella vulgaris. Environ. Pollut. 2020, 265, 114743. [CrossRef]

30. Leclerc, S.; Wilkinson, K.J. Bioaccumulation of nanosilver by Chlamydomonas reinhardtii-Nanoparticle or the free ion? Environ. Sci. Technol. 2014, 48, 358-364. [CrossRef]

31. Zhao, Z.; Xu, L.; Wang, Y.; Li, B.; Zhang, W.; Li, X. Toxicity mechanism of silver nanoparticles to Chlamydomonas reinhardtii: Photosynthesis, oxidative stress, membrane permeability, and ultrastructure analysis. Environ. Sci. Pollut. Res. 2020, 28, 15032-15042. [CrossRef]

32. Oukarroum, A.; Polchtchikov, S.; Perreault, F.; Popovic, R. Temperature influence on silver nanoparticles inhibitory effect on photosystem II photochemistry in two green algae, Chlorella vulgaris and Dunaliella tertiolecta. Environ. Sci. Pollut. Res. 2012, 19, 1755-1762. [CrossRef]

33. Kalman, J.; Paul, K.B.; Khan, F.R.; Stone, V.; Fernandes, T.F. Characterisation of bioaccumulation dynamics of three differently coated silver nanoparticles and aqueous silver in a simple freshwater food chain. Environ. Chem. 2015, 12, 662-672. [CrossRef] 
34. Hazeem, L.J.; Kuku, G.; Dewailly, E.; Slomianny, C.; Barras, A.; Hamdi, A.; Boukherroub, R.; Culha, M.; Bououdina, M. Toxicity effect of silver nanoparticles on photosynthetic pigment content, growth, ROS production and ultrastructural changes of microalgae Chlorella vulgaris. Nanomaterials 2019, 9. [CrossRef]

35. Mariano, S.; Panzarini, E.; Inverno, M.D.; Voulvoulis, N.; Dini, L. Toxicity, bioaccumulation and biotransformation of glucosecapped silver nanoparticles in green microalgae Chlorella vulgaris. Nanomaterials 2020, 10, 1377. [CrossRef] [PubMed]

36. Kennedy, A.J.; Hull, M.S.; Bednar, A.J.; Goss, J.D.; Gunter, J.C.; Bouldin, J.L.; Vikesland, P.J.; Steevens, J.A. Fractionating nanosilver: Importance for determining toxicity to aquatic test organisms. Environ. Sci. Technol. 2010, 44, 9571-9577. [CrossRef] [PubMed]

37. Angel, B.M.; Batley, G.E.; Jarolimek, C.V.; Rogers, N.J. The impact of size on the fate and toxicity of nanoparticulate silver in aquatic systems. Chemosphere 2013, 93, 359-365. [CrossRef] [PubMed]

38. Yu, S.J.; Yin, Y.G.; Liu, J.F. Silver nanoparticles in the environment. Environ. Sci. Process. Impacts 2013, 15, 78-92. [CrossRef] [PubMed]

39. Li, X.; Schirmer, K.; Bernard, L.; Sigg, L.; Pillai, S.; Behra, R. Silver nanoparticle toxicity and association with the alga Euglena gracilis. Environ. Sci. Nano 2015, 2, 594-602. [CrossRef]

40. Yue, Y.; Li, X.; Sigg, L.; Suter, M.J.F.; Pillai, S.; Behra, R.; Schirmer, K. Interaction of silver nanoparticles with algae and fish cells: A side by side comparison. J. Nanobiotechnol. 2017, 15, 1-11. [CrossRef] [PubMed]

41. Zhou, K.; Hu, Y.; Zhang, L.; Yang, K.; Lin, D. The role of exopolymeric substances in the bioaccumulation and toxicity of Ag nanoparticles to algae. Sci. Rep. 2016, 6, 1-11. [CrossRef]

42. Koczkur, K.M.; Mourdikoudis, S.; Polavarapu, L.; Skrabalak, S.E. Polyvinylpyrrolidone (PVP) in nanoparticle synthesis. Dalt. Trans. 2015, 44, 17883-17905. [CrossRef]

43. Yu, W.; Xie, H. A review on nanofluids: Preparation, stability mechanisms, and applications. J. Nanomater. 2012, 2012. [CrossRef]

44. Zhang, C.L.; Jiang, H.S.; Gu, S.P.; Zhou, X.H.; Lu, Z.W.; Kang, X.H.; Yin, L.; Huang, J. Combination analysis of the physiology and transcriptome provides insights into the mechanism of silver nanoparticles phytotoxicity. Environ. Pollut. 2019, 252, 1539-1549. [CrossRef]

45. Vannini, C.; Domingo, G.; Onelli, E.; De Mattia, F.; Bruni, I.; Marsoni, M.; Bracale, M. Phytotoxic and genotoxic effects of silver nanoparticles exposure on germinating wheat seedlings. J. Plant Physiol. 2014, 171, 1142-1148. [CrossRef]

46. Jiang, H.S.; Yin, L.Y.; Ren, N.N.; Zhao, S.T.; Li, Z.; Zhi, Y.; Shao, H.; Li, W.; Gontero, B. Silver nanoparticles induced reactive oxygen species via photosynthetic energy transport imbalance in an aquatic plant. Nanotoxicology 2017, 11, 157-167. [CrossRef]

47. Cvjetko, P.; Zovko, M.; Štefanić, P.P.; Biba, R.; Tkalec, M.; Domijan, A.M.; Vrček, I.V.; Letofsky-Papst, I.; Šikić, S.; Balen, B. Phytotoxic effects of silver nanoparticles in tobacco plants. Environ. Sci. Pollut. Res. 2018, 25, 5590-5602. [CrossRef]

48. Noori, A.; Donnelly, T.; Colbert, J.; Cai, W.; Newman, L.A.; White, J.C. Exposure of tomato (Lycopersicon esculentum) to silver nanoparticles and silver nitrate: Physiological and molecular response. Int. J. Phytoremediation 2019, 22, 40-51. [CrossRef] [PubMed]

49. Falco, W.F.; Scherer, M.D.; Oliveira, S.L.; Wender, H.; Colbeck, I.; Lawson, T.; Caires, A.R.L. Phytotoxicity of silver nanoparticles on Vicia faba: Evaluation of particle size effects on photosynthetic performance and leaf gas exchange. Sci. Total Environ. 2020, 701, 134816. [CrossRef] [PubMed]

50. Biba, R.; Matić, D.; Lyons, D.M.; Štefanić, P.P.; Cvjetko, P.; Tkalec, M.; Pavoković, D.; Letofsky-Papst, I.; Balen, B. Coatingdependent effects of silver nanoparticles on tobacco seed germination and early growth. Int. J. Mol. Sci. 2020, 21. [CrossRef] [PubMed]

51. Peharec Štefanić, P.; Košpić, K.; Lyons, D.M.; Jurković, L.; Balen, B.; Tkalec, M. Phytotoxicity of silver nanoparticles on tobacco plants: Evaluation of coating effects on photosynthetic performance and chloroplast ultrastructure. Nanomaterials 2021, 11, 744. [CrossRef]

52. Wang, J.; Koo, Y.; Alexander, A.; Yang, Y.; Westerhof, S.; Zhang, Q.; Schnoor, J.L.; Colvin, V.L.; Braam, J.; Alvarez, P.J.J. Phytostimulation of poplars and Arabidopsis exposed to silver nanoparticles and $\mathrm{Ag}^{+}$at sublethal concentrations. Environ. Sci. Technol. 2013, 47, 5442-5449. [CrossRef] [PubMed]

53. Abdelsalam, N.R.; Abdel-Megeed, A.; Ali, H.M.; Salem, M.Z.M.; Al-Hayali, M.F.A.; Elshikh, M.S. Genotoxicity effects of silver nanoparticles on wheat (Triticum aestivum L.) root tip cells. Ecotoxicol. Environ. Saf. 2018, 155, 76-85. [CrossRef]

54. Das, P.; Barua, S.; Sarkar, S.; Chatterjee, S.K.; Mukherjee, S.; Goswami, L.; Das, S.; Bhattacharya, S.; Karak, N.; Bhattacharya, S.S. Mechanism of toxicity and transformation of silver nanoparticles: Inclusive assessment in earthworm-microbe-soil-plant system. Geoderma 2018, 314, 73-84. [CrossRef]

55. Mirzajani, F.; Askari, H.; Hamzelou, S.; Farzaneh, M.; Ghassempour, A. Effect of silver nanoparticles on Oryza sativa L. and its rhizosphere bacteria. Ecotoxicol. Environ. Saf. 2013, 88, 48-54. [CrossRef]

56. Mirzajani, F.; Askari, H.; Hamzelou, S.; Schober, Y.; Römpp, A.; Ghassempour, A.; Spengler, B. Proteomics study of silver nanoparticles toxicity on Oryza sativa L. Ecotoxicol. Environ. Saf. 2014, 108, 335-339. [CrossRef] [PubMed]

57. Lalau, C.M.; Simioni, C.; Vicentini, D.S.; Ouriques, L.C.; Mohedano, R.A.; Puerari, R.C.; Matias, W.G. Toxicological effects of AgNPs on duckweed (Landoltia punctata). Sci. Total Environ. 2020, 710, 136318. [CrossRef]

58. Jiang, H.S.; Li, M.; Chang, F.Y.; Li, W.; Yin, L.Y. Physiological analysis of silver nanoparticles and $\mathrm{AgNO}_{3}$ toxicity to Spirodela polyrhiza. Environ. Toxicol. Chem. 2012, 31, 1880-1886. [CrossRef] [PubMed]

59. Kong, H.; Yang, J.; Zhang, Y.; Fang, Y.; Nishinari, K.; Phillips, G.O. Synthesis and antioxidant properties of gum arabic-stabilized selenium nanoparticles. Int. J. Biol. Macromol. 2014, 65, 155-162. [CrossRef] 
60. Biba, R.; Tkalec, M.; Cvjetko, P.; Štefanić, P.P.; Šikić, S.; Pavoković, D.; Balen, B. Silver nanoparticles affect germination and photosynthesis in tobacco seedlings. Acta Bot. Croat. 2021, 80,1-11. [CrossRef]

61. Peharec Štefanić, P.; Cvjetko, P.; Biba, R.; Domijan, A.M.; Letofsky-Papst, I.; Tkalec, M.; Šikić, S.; Cindrić, M.; Balen, B. Physiological, ultrastructural and proteomic responses of tobacco seedlings exposed to silver nanoparticles and silver nitrate. Chemosphere 2018, 209, 640-653. [CrossRef]

62. Gubbins, E.J.; Batty, L.C.; Lead, J.R. Phytotoxicity of silver nanoparticles to Lemna minor L. Environ. Pollut. 2011, 159, 1551-1559. [CrossRef]

63. Abdel-Aziz, H.M.M.; Rizwan, M. Chemically synthesized silver nanoparticles induced physio-chemical and chloroplast ultrastructural changes in broad bean seedlings. Chemosphere 2019, 235, 1066-1072. [CrossRef]

64. Li, Y.; Zhang, W.; Niu, J.; Chen, Y. Surface-coating-dependent dissolution, aggregation, and reactive oxygen species (ROS) generation of silver nanoparticles under different irradiation conditions. Environ. Sci. Technol. 2013, 47, 10293-10301. [CrossRef] [PubMed]

65. Cvjetko, P.; Milošić, A.; Domijan, A.M.; Vinković Vrček, I.; Tolić, S.; Peharec Štefanić, P.; Letofsky-Papst, I.; Tkalec, M.; Balen, B. Toxicity of silver ions and differently coated silver nanoparticles in Allium cepa roots. Ecotoxicol. Environ. Saf. 2017, 137, 18-28. [CrossRef] [PubMed]

66. Barabanov, P.V.; Gerasimov, A.V.; Blinov, A.V.; Kravtsov, A.A.; Kravtsov, V.A. Influence of nanosilver on the efficiency of Pisum sativum crops germination. Ecotoxicol. Environ. Saf. 2018, 147, 715-719. [CrossRef]

67. Gusev, A.A.; Kudrinsky, A.A.; Zakharova, O.V.; Klimov, A.I.; Zherebin, P.M.; Lisichkin, G.V.; Vasyukova, I.A.; Denisov, A.N.; Krutyakov, Y.A. Versatile synthesis of PHMB-stabilized silver nanoparticles and their significant stimulating effect on fodder beet (Beta vulgaris L.). Mater. Sci. Eng. C 2016, 62, 152-159. [CrossRef]

68. Zhao, C.M.; Wang, W.X. Importance of surface coatings and soluble silver in silver nanoparticles toxicity to Daphnia magna. Nanotoxicology 2012, 6, 361-370. [CrossRef]

69. Liu, W.; Zhou, Q.F.; Liu, J.Y.; Fu, J.J.; Liu, S.J.; Jiang, G. Bin Environmental and biological influences on the stability of silver nanoparticles. Chinese Sci. Bull. 2011, 56, 2009-2015. [CrossRef]

70. Argentiere, S.; Cella, C.; Cesaria, M.; Milani, P.; Lenardi, C. Silver nanoparticles in complex biological media: Assessment of colloidal stability and protein corona formation. J. Nanoparticle Res. 2016, 18. [CrossRef]

71. Pem, B.; Ćurlin, M.; Jurašin, D.D.; Vrček, V.; Barbir, R.; Micek, V.; Fratila, R.M.; de la Fuente, J.M.; Vrček, I.V. Fate and transformation of silver nanoparticles in different biological conditions. Beilstein J. Nanotechnol. 2021, 12, 665-679. [CrossRef] [PubMed]

72. MacCuspie, R.I. Colloidal stability of silver nanoparticles in biologically relevant conditions. J. Nanoparticle Res. 2011, 13, 2893-2908. [CrossRef]

73. Akter, M.; Sikder, M.T.; Rahman, M.M.; Ullah, A.K.M.A.; Hossain, K.F.B.; Banik, S.; Hosokawa, T.; Saito, T.; Kurasaki, M. A systematic review on silver nanoparticles-induced cytotoxicity: Physicochemical properties and perspectives. J. Adv. Res. 2018, 9, 1-16. [CrossRef] [PubMed]

74. Tripathi, D.K.; Tripathi, A.; Shweta; Singh, S.; Singh, Y.; Vishwakarma, K.; Yadav, G.; Sharma, S.; Singh, V.K.; Mishra, R.K.; et al. Uptake, accumulation and toxicity of silver nanoparticle in autotrophic plants, and heterotrophic microbes: A concentric review. Front. Microbiol. 2017, 8, 1-16. [CrossRef]

75. Tejamaya, M.; Römer, I.; Merrifield, R.C.; Lead, J.R. Stability of citrate, PVP, and PEG coated silver nanoparticles in ecotoxicology media. Environ. Sci. Technol. 2012, 46, 7011-7017. [CrossRef] [PubMed]

76. Azodi, M.; Sultan, Y.; Ghoshal, S. Dissolution behavior of silver nanoparticles and formation of secondary silver nanoparticles in municipal wastewater by single-particle ICP-MS. Environ. Sci. Technol. 2016, 50, 13318-13327. [CrossRef] [PubMed]

77. Reidy, B.; Haase, A.; Luch, A.; Dawson, K.A.; Lynch, I. Mechanisms of silver nanoparticle release, transformation and toxicity: A critical review of current knowledge and recommendations for future studies and applications. Materials 2013, 6, 2295-2350. [CrossRef] [PubMed]

78. Muraleetharan, V.; Mantaj, J.; Swedrowska, M.; Vllasaliu, D. Nanoparticle modification in biological media: Implications for oral nanomedicines. RSC Adv. 2019, 9, 40487-40497. [CrossRef]

79. Thwala, M.; Musee, N.; Sikhwivhilu, L.; Wepener, V. The oxidative toxicity of Ag and ZnO nanoparticles towards the aquatic plant Spirodela punctuta and the role of testing media parameters. Environ. Sci. Process. Impacts 2013, 15, 1830-1843. [CrossRef] [PubMed]

80. Nair, P.M.G.; Chung, I.M. Assessment of silver nanoparticle-induced physiological and molecular changes in Arabidopsis thaliana. Environ. Sci. Pollut. Res. 2014, 21, 8858-8869. [CrossRef] [PubMed]

81. Dimkpa, C.O.; McLean, J.E.; Martineau, N.; Britt, D.W.; Haverkamp, R.; Anderson, A.J. Silver nanoparticles disrupt wheat (Triticum aestivum L.) growth in a sand matrix. Environ. Sci. Technol. 2013, 47, 1082-1090. [CrossRef]

82. Patlolla, A.K.; Berry, A.; May, L.; Tchounwou, P.B. Genotoxicity of silver nanoparticles in Vicia faba: A pilot study on the environmental monitoring of nanoparticles. Int. J. Environ. Res. Public Health 2012, 9, 1649-1662. [CrossRef] [PubMed]

83. Barrena, R.; Casals, E.; Colón, J.; Font, X.; Sánchez, A.; Puntes, V. Evaluation of the ecotoxicity of model nanoparticles. Chemosphere 2009, 75, 850-857. [CrossRef]

84. Ju-Nam, Y.; Lead, J.R. Manufactured nanoparticles: An overview of their chemistry, interactions and potential environmental implications. Sci. Total Environ. 2008, 400, 396-414. [CrossRef] [PubMed] 
85. Kvítek, L.; Panáček, A.; Soukupová, J.; Kolář, M.; Večeřová, R.; Prucek, R.; Holecová, M.; Zbořil, R. Effect of surfactants and polymers on stability and antibacterial activity of silver nanoparticles (NPs). J. Phys. Chem. C 2008, 112, 5825-5834. [CrossRef]

86. Cartwright, A.; Jackson, K.; Morgan, C.; Anderson, A.; Britt, D.W. A review of metal and metal-oxide nanoparticle coating technologies to inhibit agglomeration and increase bioactivity for agricultural applications. Agronomy 2020, 10, 1018. [CrossRef]

87. Schubert, J.; Chanana, M. Coating matters: Review on colloidal stability of nanoparticles with biocompatible coatings in biological media, living cells and organisms. Curr. Med. Chem. 2018, 25, 4553-4586. [CrossRef] [PubMed]

88. Pokhrel, L.R.; Dubey, B. Evaluation of developmental responses of two crop plants exposed to silver and zinc oxide nanoparticles. Sci. Total Environ. 2013, 452-453, 321-332. [CrossRef] [PubMed]

89. Peharec Štefanić, P.; Jarnević, M.; Cvjetko, P.; Biba, R.; Šikić, S.; Tkalec, M.; Cindrić, M.; Letofsky-Papst, I.; Balen, B. Comparative proteomic study of phytotoxic effects of silver nanoparticles and silver ions on tobacco plants. Environ. Sci. Pollut. Res. 2019, 26, 22529-22550. [CrossRef] [PubMed]

90. Ke, M.; Qu, Q.; Peijnenburg, W.J.G.M.; Li, X.; Zhang, M.; Zhang, Z.; Lu, T.; Pan, X.; Qian, H. Phytotoxic effects of silver nanoparticles and silver ions to Arabidopsis thaliana as revealed by analysis of molecular responses and of metabolic pathways. Sci. Total Environ. 2018, 644, 1070-1079. [CrossRef] [PubMed]

91. Geisler-Lee, J.; Wang, Q.; Yao, Y.; Zhang, W.; Geisler, M.; Li, K.; Huang, Y.; Chen, Y.; Kolmakov, A.; Ma, X. Phytotoxicity, accumulation and transport of silver nanoparticles by Arabidopsis thaliana. Nanotoxicology 2013, 7, 323-337. [CrossRef]

92. Li, X.; Ke, M.; Zhang, M.; Peijnenburg, W.J.G.M.; Fan, X.; Xu, J.; Zhang, Z.; Lu, T.; Fu, Z.; Qian, H. The interactive effects of diclofop-methyl and silver nanoparticles on Arabidopsis thaliana: Growth, photosynthesis and antioxidant system. Environ. Pollut. 2017, 232, 212-219. [CrossRef] [PubMed]

93. Li, X.; Lenhart, J.J.; Walker, H.W. Dissolution-accompanied aggregation kinetics of silver nanoparticles. Langmuir 2010, 26, 16690-16698. [CrossRef] [PubMed]

94. Saleeb, N.; Gooneratne, R.; Cavanagh, J.; Bunt, C.; Hossain, A.K.M.M.; Gaw, S.; Robinson, B. The mobility of silver nanoparticles and silver ions in the soil-plant system. J. Environ. Qual. 2019, 48, 1835-1841. [CrossRef]

95. Lee, W.M.; Kwak, J., II; An, Y.J. Effect of silver nanoparticles in crop plants Phaseolus radiatus and Sorghum bicolor: Media effect on phytotoxicity. Chemosphere 2012, 86, 491-499. [CrossRef]

96. Fernando, I.; Zhou, Y. Impact of $\mathrm{pH}$ on the stability, dissolution and aggregation kinetics of silver nanoparticles. Chemosphere 2019, 216, 297-305. [CrossRef]

97. Moore, T.L.; Rodriguez-Lorenzo, L.; Hirsch, V.; Balog, S.; Urban, D.; Jud, C.; Rothen-Rutishauser, B.; Lattuada, M.; Petri-Fink, A. Nanoparticle colloidal stability in cell culture media and impact on cellular interactions. Chem. Soc. Rev. 2015, 44, 6287-6305. [CrossRef] [PubMed]

98. Mogoşanu, G.D.; Grumezescu, A.M.; Bejenaru, C.; Bejenaru, L.E. Polymeric protective agents for nanoparticles in drug delivery and targeting. Int. J. Pharm. 2016, 510, 419-429. [CrossRef] [PubMed]

99. Stegemeier, J.P.; Colman, B.P.; Schwab, F.; Wiesner, M.R.; Lowry, G.V. Uptake and distribution of silver in the aquatic plant Landoltia punctata (duckweed) exposed to silver and silver sulfide nanoparticles. Environ. Sci. Technol. 2017, 51, 4936-4943. [CrossRef] [PubMed]

100. Jiang, H.S.; Qiu, X.N.; Li, G.B.; Li, W.; Yin, L.Y. Silver nanoparticles induced accumulation of reactive oxygen species and alteration of antioxidant systems in the aquatic plant Spirodela polyrhiza. Environ. Toxicol. Chem. 2014, 33, 1398-1405. [CrossRef]

101. Yang, Q.; Shan, W.; Hu, L.; Zhao, Y.; Hou, Y.; Yin, Y.; Liang, Y.; Wang, F.; Cai, Y.; Liu, J.; et al. Uptake and transformation of silver nanoparticles and ions by rice plants revealed by dual stable isotope tracing. Environ. Sci. Technol. 2019, 53, 625-633. [CrossRef]

102. Yang, Q.; Xu, W.; Liu, G.; Song, M.; Tan, Z.; Mao, Y.; Yin, Y.; Cai, Y.; Liu, J.; Jiang, G. Transformation and uptake of silver nanoparticles and silver ions in rice plant (Oryza sativa L.): The effect of iron plaque and dissolved iron. Environ. Sci. Nano 2020, 7 , 599-609. [CrossRef]

103. Lv, J.; Christie, P.; Zhang, S. Uptake, translocation, and transformation of metal-based nanoparticles in plants: Recent advances and methodological challenges. Environ. Sci. Nano 2019, 6, 41-59. [CrossRef]

104. Wheeler, K.E.; Chetwynd, A.J.; Fahy, K.M.; Hong, B.S.; Tochihuitl, J.A.; Foster, L.A.; Lynch, I. Environmental dimensions of the protein corona. Nat. Nanotechnol. 2021, 16, 617-629. [CrossRef]

105. Szőllősi, R.; Molnár, Á.; Kondak, S.; Kolbert, Z. Dual effect of nanomaterials on germination and seedling growth: Stimulation vs. phytotoxicity. Plants 2020, 9, 1745. [CrossRef] [PubMed]

106. Tymoszuk, A. Silver nanoparticles effects on in vitro germination, growth, and biochemical activity of tomato, radish, and kale seedlings. Materials 2021, 14. [CrossRef] [PubMed]

107. Pacheco, I.; Buzea, C. Nanoparticle interaction with plants. In Nanoscience and Plant-Soil Systems. Soil Biology, Vol. 48; Ghorbanpour, M., Manika, K., Varma, A., Eds.; Springer: Berlin, Germany, 2017; pp. 323-355, ISBN 9783319468358.

108. Navarro, E.; Piccapietra, F.; Wagner, B.; Marconi, F.; Kaegi, R.; Odzak, N.; Sigg, L.; Behra, R. Toxicity of silver nanoparticles to Chlamydomonas reinhardtii. Environ. Sci. Technol. 2008, 42, 8959-8964. [CrossRef]

109. Fabrega, J.; Luoma, S.N.; Tyler, C.R.; Galloway, T.S.; Lead, J.R. Silver nanoparticles: Behaviour and effects in the aquatic environment. Environ. Int. 2011, 37, 517-531. [CrossRef] [PubMed]

110. Мa, X.; Geiser-Lee, J.; Deng, Y.; Kolmakov, A. Interactions between engineered nanoparticles (ENPs) and plants: Phytotoxicity, uptake and accumulation. Sci. Total Environ. 2010, 408, 3053-3061. [CrossRef] 
111. Yan, A.; Chen, Z. Impacts of silver nanoparticles on plants: A focus on the phytotoxicity and underlying mechanism. Int. J. Mol. Sci. 2019, 20, 1003. [CrossRef]

112. Prażak, R.; Święciło, A.; Krzepiłko, A.; Michałek, S.; Arczewska, M. Impact of Ag nanoparticles on seed germination and seedling growth of green beans in normal and chill temperatures. Agriculture 2020, 10, 312. [CrossRef]

113. Song, U.; Jun, H.; Waldman, B.; Roh, J.; Kim, Y.; Yi, J.; Lee, E.J. Functional analyses of nanoparticle toxicity: A comparative study of the effects of $\mathrm{TiO}_{2}$ and $\mathrm{Ag}$ on tomatoes (Lycopersicon esculentum). Ecotoxicol. Environ. Saf. 2013, 93, 60-67. [CrossRef] [PubMed]

114. Geisler-Lee, J.; Brooks, M.; Gerfen, J.; Wang, Q.; Fotis, C.; Sparer, A.; Ma, X.; Berg, R.; Geisler, M. Reproductive toxicity and life history study of silver nanoparticle effect, uptake and transport in Arabidopsis thaliana. Nanomaterials 2014, 4, 301-318. [CrossRef]

115. Scherer, M.D.; Sposito, J.C.V.; Falco, W.F.; Grisolia, A.B.; Andrade, L.H.C.; Lima, S.M.; Machado, G.; Nascimento, V.A.; Gonçalves, D.A.; Wender, H.; et al. Cytotoxic and genotoxic effects of silver nanoparticles on meristematic cells of Allium cepa roots: A close analysis of particle size dependence. Sci. Total Environ. 2019, 660, 459-467. [CrossRef] [PubMed]

116. Vannini, C.; Domingo, G.; Onelli, E.; Prinsi, B.; Marsoni, M.; Espen, L.; Bracale, M. Morphological and proteomic responses of Eruca sativa exposed to silver nanoparticles or silver nitrate. PLoS ONE 2013, 8. [CrossRef] [PubMed]

117. Yasur, J.; Rani, P.U. Environmental effects of nanosilver: Impact on castor seed germination, seedling growth, and plant physiology. Environ. Sci. Pollut. Res. 2013, 20, 8636-8648. [CrossRef]

118. Wang, L.; Sun, J.; Lin, L.; Fu, Y.; Alenius, H.; Lindsey, K.; Chen, C. Silver nanoparticles regulate Arabidopsis root growth by concentration-dependent modification of reactive oxygen species accumulation and cell division. Ecotoxicol. Environ. Saf. 2020, 190, 1-9. [CrossRef] [PubMed]

119. Yin, L.; Colman, B.P.; McGill, B.M.; Wright, J.P.; Bernhardt, E.S. Effects of silver nanoparticle exposure on germination and early growth of eleven wetland plants. PLoS ONE 2012, 7. [CrossRef]

120. Pereira, S.P.P.; Jesus, F.; Aguiar, S.; de Oliveira, R.; Fernandes, M.; Ranville, J.; Nogueira, A.J.A. Phytotoxicity of silver nanoparticles to Lemna minor: Surface coating and exposure period-related effects. Sci. Total Environ. 2018, 618, 1389-1399. [CrossRef] [PubMed]

121. Liang, L.; Tang, H.; Deng, Z.; Liu, Y.; Chen, X.; Wang, H. Ag nanoparticles inhibit the growth of the bryophyte, Physcomitrella patens. Ecotoxicol. Environ. Saf. 2018, 164, 739-748. [CrossRef] [PubMed]

122. Wang, F.; Guan, W.; Xu, L.; Ding, Z.; Ma, H.; Ma, A.; Terry, N. Effects of nanoparticles on algae: Adsorption, distribution, ecotoxicity and fate. Appl. Sci. 2019, 9, 1534. [CrossRef]

123. Xia, B.; Chen, B.; Sun, X.; Qu, K.; Ma, F.; Du, M. Interaction of $\mathrm{TiO}_{2}$ nanoparticles with the marine microalga Nitzschia closterium: Growth inhibition, oxidative stress and internalization. Sci. Total Environ. 2015, 508, 525-533. [CrossRef] [PubMed]

124. Xiang, L.; Fang, J.; Cheng, H. Toxicity of silver nanoparticles to green algae M. aeruginosa and alleviation by organic matter. Environ. Monit. Assess. 2018, 190. [CrossRef]

125. Miao, A.J.; Schwehr, K.A.; Xu, C.; Zhang, S.J.; Luo, Z.; Quigg, A.; Santschi, P.H. The algal toxicity of silver engineered nanoparticles and detoxification by exopolymeric substances. Environ. Pollut. 2009, 157, 3034-3041. [CrossRef] [PubMed]

126. Ribeiro, F.; Gallego-Urrea, J.A.; Goodhead, R.M.; Van Gestel, C.A.M.; Moger, J.; Soares, A.M.V.M.; Loureiro, S. Uptake and elimination kinetics of silver nanoparticles and silver nitrate by Raphidocelis subcapitata: The influence of silver behaviour in solution. Nanotoxicology 2015, 9, 686-695. [CrossRef] [PubMed]

127. Peulen, T.O.; Wilkinson, K.J. Diffusion of nanoparticles in a biofilm. Environ. Sci. Technol. 2011, 45, 3367-3373. [CrossRef] [PubMed]

128. Flores-López, L.Z.; Espinoza-Gómez, H.; Somanathan, R. Silver nanoparticles: Electron transfer, reactive oxygen species, oxidative stress, beneficial and toxicological effects. Mini review. J. Appl. Toxicol. 2019, 39, 16-26. [CrossRef]

129. Dayem, A.A.; Hossain, M.K.; Lee, S.B.; Kim, K.; Saha, S.K.; Yang, G.M.; Choi, H.Y.; Cho, S.G. The role of reactive oxygen species (ROS) in the biological activities of metallic nanoparticles. Int. J. Mol. Sci. 2017, 18, 120. [CrossRef] [PubMed]

130. Khanna, P.; Ong, C.; Bay, B.H.; Baeg, G.H. Nanotoxicity: An interplay of oxidative stress, inflammation and cell death. Nanomaterials 2015, 5, 1163-1180. [CrossRef] [PubMed]

131. Vallejo, M.J.; Salazar, L.; Grijalva, M. Oxidative stress modulation and ROS-mediated toxicity in cancer: A review on in vitro models for plant-derived compounds. Oxid. Med. Cell. Longev. 2017, 2017. [CrossRef]

132. Wijnhoven, S.W.P.; Peijnenburg, W.J.G.M.; Herberts, C.A.; Hagens, W.I.; Oomen, A.G.; Heugens, E.H.W.; Roszek, B.; Bisschops, J.; Gosens, I.; Van De Meent, D.; et al. Nano-silver-A review of available data and knowledge gaps in human and environmental risk assessment. Nanotoxicology 2009, 3, 109-138. [CrossRef]

133. McShan, D.; Ray, P.C.; Yu, H. Molecular toxicity mechanism of nanosilver. J. Food Drug Anal. 2014, 22, 116-127. [CrossRef]

134. Panáček, A.; Kvítek, L.; Prucek, R.; Kolář, M.; Večeřová, R.; Pizúrová, N.; Sharma, V.K.; Nevěčná, T.; Zbořil, R. Silver colloid nanoparticles: Synthesis, characterization, and their antibacterial activity. J. Phys. Chem. B 2006, 110, 16248-16253. [CrossRef]

135. Souza, I.R.; Silva, L.R.; Fernandes, L.S.P.; Salgado, L.D.; Silva de Assis, H.C.; Firak, D.S.; Bach, L.; Santos-Filho, R.; Voigt, C.L.; Barros, A.C.; et al. Visible-light reduced silver nanoparticles' toxicity in Allium cepa test system. Environ. Pollut. 2019, $257,113551$. [CrossRef] [PubMed]

136. Nel, A.; Xia, T.; Madler, L.; Li, N. Toxic potential of materials at the nanolevel. Science 2006, 311, 622-627. [CrossRef] [PubMed]

137. Lekamge, S.; Miranda, A.F.; Trestrail, C.; Pham, B.; Ball, A.S.; Shukla, R.; Nugegoda, D. The toxicity of nonaged and aged coated silver nanoparticles to freshwater alga Raphidocelis subcapitata. Environ. Toxicol. Chem. 2019, 38, 2371-2382. [CrossRef]

138. Szivák, I.; Behra, R.; Sigg, L. Metal-induced reactive oxygen species production in Chlamydomonas reinhardtii (Chlorophyceae). J. Phycol. 2009, 45, 427-435. [CrossRef] 
139. Galazzi, R.M.; Lopes Júnior, C.A.; de Lima, T.B.; Gozzo, F.C.; Arruda, M.A.Z. Evaluation of some effects on plant metabolism through proteins and enzymes in transgenic and non-transgenic soybeans after cultivation with silver nanoparticles. J. Proteom. 2019, 191, 88-106. [CrossRef]

140. Oukarroum, A.; Samadani, M.; Dewez, D. Influence of $\mathrm{pH}$ on the toxicity of silver nanoparticles in the green alga Chlamydomonas acidophila. Water. Air. Soil Pollut. 2014, 225. [CrossRef]

141. Nair, P.M.G.; Chung, I.M. Physiological and molecular level effects of silver nanoparticles exposure in rice (Oryza sativa L.) seedlings. Chemosphere 2014, 112, 105-113. [CrossRef] [PubMed]

142. Speranza, A.; Crinelli, R.; Scoccianti, V.; Taddei, A.R.; Iacobucci, M.; Bhattacharya, P.; Ke, P.C. In vitro toxicity of silver nanoparticles to kiwifruit pollen exhibits peculiar traits beyond the cause of silver ion release. Environ. Pollut. 2013, 179, $258-267$. [CrossRef]

143. Lu, G.; Yang, H.; Xia, J.; Zong, Y.; Liu, J. Toxicity of Cu and Cr nanoparticles to Daphnia magna. Water. Air. Soil Pollut. 2017, 228. [CrossRef]

144. Khromykh, N.O.; Shupranova, L.V.; Lykholat, Y.V.; Bil'chuk, V.S.; Fedenko, V.S.; Boguslavs'ka, L.V.; Borysova, O.I. Physiological and biochemical reactions of Hordeum vulgare seedlings to the action of silver nanoparticles. Biosyst. Divers. 2015, 23, 100-104. [CrossRef]

145. Hayat, S.; Hayat, Q.; Alyemeni, M.N.; Wani, A.S.; Pichtel, J.; Ahmad, A. Role of proline under changing environments: A review. Plant Signal. Behav. 2012, 7, 1456-1466. [CrossRef] [PubMed]

146. Sinha, S.; Saxena, R. Effect of iron on lipid peroxidation, and enzymatic and non-enzymatic antioxidants and bacoside - A content in medicinal plant Bacopa monnieri L. Chemosphere 2006, 62, 1340-1350. [CrossRef] [PubMed]

147. Chiang, H.-H.; Dandekar, A.M. Regulation of proline accumulation in Arabidopsis thaliana (L.) Heynh during development and in response to desiccation. Plant. Cell Environ. 1995, 18, 1280-1290. [CrossRef]

148. Lee, S.; Pagoria, D.; Raigrodski, A.; Geurtsen, W. Effects of combinations of ROS scavengers on oxidative DNA damage caused by visible-light-activated camphorquinone/N,N-dimethyl-p-toluidine. J. Biomed. Mater. Res. 2007, 83, 391-399. [CrossRef]

149. Ha, A.S.; Smith, A.P.; Howden, R.; Dietrich, W.M.; Bugg, S.; Connell, M.J.O.; Goldsbrough, P.B.; Cobbett, C.S.; The, S.; Cell, P.; et al Phytochelatin synthase genes from Arabidopsis and the yeast Schizosaccharomyces pombe. Plant Cell 1999, 11, 1153-1163. [CrossRef]

150. Havaux, M. Carotenoid oxidation products as stress signals in plants. Plant J. 2014, 79, 597-606. [CrossRef]

151. Karimi, J.; Mohsenzadeh, S. Physiological effects of silver nanoparticles and silver nitrate toxicity in Triticum aestivum. Iran. J. Sci. Technol. Trans. A Sci. 2017, 41, 111-120. [CrossRef]

152. Safafar, H.; Wagenen, J.V.; Møller, P.; Jacobsen, C. Carotenoids, phenolic compounds and tocopherols contribute to the antioxidative properties of some microalgae species grown on industrial wastewater. Mar. Drugs 2015, 13, 7339-7356. [CrossRef] [PubMed]

153. Chandra, R.; Bharagava, R.N.; Yadav, S.; Mohan, D. Accumulation and distribution of toxic metals in wheat (Triticum aestivum L.) and Indian mustard (Brassica campestris L.) irrigated with distillery and tannery effluents. J. Hazard. Mater. 2009, 162, $1514-1521$. [CrossRef]

154. Sharma, P.; Dubey, R.S. Lead toxicity in plants. Braz. J. Plant Physiol. 2005, 17, 35-52. [CrossRef]

155. Szabados, L.; Savouré, A. Proline: A multifunctional amino acid. Trends Plant Sci. 2010, 15, 89-97. [CrossRef] [PubMed]

156. Lovecká, P.; Macůrková, A.; Záruba, K.; Hubáček, T.; Siegel, J.; Valentová, O. Genomic damage induced in Nicotiana tabacum L. plants by colloidal solution with silver and gold nanoparticles. Plants 2021, 10, 1260. [CrossRef] [PubMed]

157. Shigenaga, M.K.; Ames, B. Oxidants and mitogenesis as causes of mutation and cancer: The influence of diet. Basic Life Sci 1993, 61, 419-436. [PubMed]

158. Kumari, M.; Mukherjee, A.; Chandrasekaran, N. Genotoxicity of silver nanoparticles in Allium cepa. Sci. Total Environ. 2009, 407, 5243-5246. [CrossRef]

159. Hafez, R.M.; Fouad, A.S. Mitigation of genotoxic and cytotoxic effects of silver nanoparticles on onion root tips using some antioxidant scavengers. Egypt. J. Bot. 2020, 60, 133-145. [CrossRef]

160. Casillas-Figueroa, F.; Arellano-García, M.E.; Leyva-Aguilera, C.; Ruíz-Ruíz, B.; Vázquez-Gómez, R.L.; Radilla-Chávez, P.; ChávezSantoscoy, R.A.; Pestryakov, A.; Toledano-Magaña, Y.; García-Ramos, J.C.; et al. Argovit ${ }^{\mathrm{TM}}$ silver nanoparticles effects on Allium cepa: Plant growth promotion without cyto genotoxic damage. Nanomaterials 2020, 10, 1386. [CrossRef]

161. Pesnya, D.S. Cytogenetic effects of chitosan-capped silver nanoparticles in the Allium cepa test. Caryologia 2013, 66, 275-281. [CrossRef]

162. Abbas, Q.; Liu, G.; Yousaf, B.; Ali, M.U.; Ullah, H.; Ahmed, R. Effects of biochar on uptake, acquisition and translocation of silver nanoparticles in rice (Oryza sativa L.) in relation to growth, photosynthetic traits and nutrients displacement. Environ. Pollut. 2019, 250, 728-736. [CrossRef]

163. Qian, H.; Peng, X.; Han, X.; Ren, J.; Sun, L.; Fu, Z. Comparison of the toxicity of silver nanoparticles and silver ions on the growth of terrestrial plant model Arabidopsis thaliana. J. Environ. Sci. 2013, 25, 1947-1956. [CrossRef]

164. Zou, X.; Li, P.; Lou, J.; Zhang, H. Surface coating-modulated toxic responses to silver nanoparticles in Wolffia globosa. Aquat. Toxicol. 2017, 189, 150-158. [CrossRef] [PubMed]

165. Dewez, D.; Goltsev, V.; Kalaji, H.M.; Oukarroum, A. Inhibitory effects of silver nanoparticles on photosystem II performance in Lemna gibba probed by chlorophyll fluorescence. Curr. Plant Biol. 2018, 16, 15-21. [CrossRef] 
166. Sosan, A.; Svistunenko, D.; Straltsova, D.; Tsiurkina, K.; Smolich, I.; Lawson, T.; Subramaniam, S.; Golovko, V.; Anderson, D.; Sokolik, A.; et al. Engineered silver nanoparticles are sensed at the plasma membrane and dramatically modify the physiology of Arabidopsis thaliana plants. Plant J. 2016, 85, 245-257. [CrossRef]

167. Jansson, H.; Hansson, Ö. Competitive inhibition of electron donation to photosystem 1 by metal-substituted plastocyanin. Biochim. Biophys. Acta Bioenerg. 2008, 1777, 1116-1121. [CrossRef] [PubMed]

168. Xu, Q.S.; Hu, J.Z.; Xie, K.B.; Yang, H.Y.; Du, K.H.; Shi, G.X. Accumulation and acute toxicity of silver in Potamogeton crispus L. J. Hazard. Mater. 2010, 173, 186-193. [CrossRef] [PubMed]

169. Torrent, L.; Iglesias, M.; Marguí, E.; Hidalgo, M.; Verdaguer, D.; Llorens, L.; Kodre, A.; Kavčič, A.; Vogel-Mikuš, K. Uptake, translocation and ligand of silver in Lactuca sativa exposed to silver nanoparticles of different size, coatings and concentration. $J$. Hazard. Mater. 2020, 384, 121201. [CrossRef] [PubMed]

170. Sadak, M.S. Impact of silver nanoparticles on plant growth, some biochemical aspects, and yield of fenugreek plant (Trigonella foenum-graecum). Bull. Natl. Res. Cent. 2019, 43. [CrossRef]

171. Spinoso-Castillo, J.L.; Chavez-Santoscoy, R.A.; Bogdanchikova, N.; Pérez-Sato, J.A.; Morales-Ramos, V.; Bello-Bello, J.J. Antimicrobial and hormetic effects of silver nanoparticles on in vitro regeneration of vanilla (Vanilla planifolia Jacks. ex Andrews) using a temporary immersion system. Plant Cell. Tissue Organ Cult. 2017, 129, 195-207. [CrossRef]

172. Bello-Bello, J.J.; Chavez-Santoscoy, R.A.; Lecona-Guzmán, C.A.; Bogdanchikova, N.; Salinas-Ruíz, J.; Gómez-Merino, F.C.; Pestryakov, A. Hormetic response by silver nanoparticles on in vitro multiplication of sugarcane (Saccharum spp. Cv. Mex 69-290) using a temporary immersion system. Dose-Response 2017, 15, 1-9. [CrossRef] [PubMed]

173. Sharma, P.; Bhatt, D.; Zaidi, M.G.H.; Saradhi, P.P.; Khanna, P.K.; Arora, S. Silver nanoparticle-mediated enhancement in growth and antioxidant status of Brassica juncea. Appl. Biochem. Biotechnol. 2012, 167, 2225-2233. [CrossRef] [PubMed]

174. Larue, C.; Castillo-Michel, H.; Sobanska, S.; Cécillon, L.; Bureau, S.; Barthès, V.; Ouerdane, L.; Carrière, M.; Sarret, G. Foliar exposure of the crop Lactuca sativa to silver nanoparticles: Evidence for internalization and changes in Ag speciation. J. Hazard. Mater. 2014, 264, 98-106. [CrossRef]

175. Castro-González, C.G.; Sánchez-Segura, L.; Gómez-Merino, F.C.; Bello-Bello, J.J. Exposure of stevia (Stevia rebaudiana B.) to silver nanoparticles in vitro: Transport and accumulation. Sci. Rep. 2019, 9, 1-10. [CrossRef]

176. Salachna, P.; Byczyńska, A.; Zawadzińska, A.; Piechocki, R.; Mizielińska, M. Stimulatory effect of silver nanoparticles on the growth and flowering of potted oriental lilies. Agronomy 2019, 9, 610. [CrossRef]

177. Gondikas, A.P.; Morris, A.; Reinsch, B.C.; Marinakos, S.M.; Lowry, G.V.; Hsu-Kim, H. Cysteine-induced modifications of zerovalent silver nanomaterials: Implications for particle surface chemistry, aggregation, dissolution, and silver speciation. Environ. Sci. Technol. 2012, 46, 7037-7045. [CrossRef]

178. Kaveh, R.; Li, Y.S.; Ranjbar, S.; Tehrani, R.; Brueck, C.L.; Van Aken, B. Changes in Arabidopsis thaliana gene expression in response to silver nanoparticles and silver ions. Environ. Sci. Technol. 2013, 47, 10637-10644. [CrossRef]

179. Pradas Del Real, A.E.; Vidal, V.; Carrière, M.; Castillo-Michel, H.; Levard, C.; Chaurand, P.; Sarret, G. Silver nanoparticles and wheat roots: A complex interplay. Environ. Sci. Technol. 2017, 51, 5774-5782. [CrossRef] [PubMed]

180. Noori, A.; Bharath, L.P.; White, J.C. Type-specific impacts of silver on the protein profile of tomato (Lycopersicon esculentum L.). Int J. Phytoremediation 2021, 1-13. [CrossRef]

181. Schiavon, M.; Wirtz, M.; Borsa, P.; Quaggiotti, S.; Hell, R.; Malagoli, M. Chromate differentially affects the expression of a high-affinity sulfate transporter and isoforms of components of the sulfate assimilatory pathway in Zea mays (L.). Plant Biol. 2007, 9, 662-671. [CrossRef] [PubMed]

182. Waśkiewicz, A.; Beszterda, M.; Goliński, P. Nonenzymatic antioxidants in plants. In Oxidative Damage to Plants: Antioxidant Networks and Signaling; Parvaiz, A., Ed.; Elsevier: Amsterdam, The Netherlands, 2014; pp. 201-234, ISBN 9780127999630.

183. García-Sánchez, S.; Bernales, I.; Cristobal, S. Early response to nanoparticles in the Arabidopsis transcriptome compromises plant defence and root-hair development through salicylic acid signalling. BMC Genom. 2015, 16. [CrossRef] [PubMed]

184. Wang, P.; Lombi, E.; Sun, S.; Scheckel, K.G.; Malysheva, A.; McKenna, B.A.; Menzies, N.W.; Zhao, F.J.; Kopittke, P.M. Characterizing the uptake, accumulation and toxicity of silver sulfide nanoparticles in plants. Environ. Sci. Nano 2017, 4, 448-460. [CrossRef]

185. Liu, J.; Zhang, H.; Yan, L.; Kerr, P.G.; Zhang, S.; Wu, Y. Electron transport, light energy conversion and proteomic responses of periphyton in photosynthesis under exposure to AgNPs. J. Hazard. Mater. 2021, 401, 123809. [CrossRef] [PubMed]

186. Sun, J.; Wang, L.; Li, S.; Yin, L.; Huang, J.; Chen, C. Toxicity of silver nanoparticles to Arabidopsis: Inhibition of root gravitropism by interfering with auxin pathway. Environ. Toxicol. Chem. 2017, 36, 2773-2780. [CrossRef] [PubMed] 